\title{
High School Teachers' Perceptions of Cyber Bullying Prevention and Intervention Strategies
}

\author{
Sterling V. Stauffer \\ Brigham Young University - Provo
}

Follow this and additional works at: https://scholarsarchive.byu.edu/etd

Part of the Counseling Psychology Commons, and the Special Education and Teaching Commons

\section{BYU ScholarsArchive Citation}

Stauffer, Sterling V., "High School Teachers' Perceptions of Cyber Bullying Prevention and Intervention Strategies" (2011). Theses and Dissertations. 2778.

https://scholarsarchive.byu.edu/etd/2778

This Thesis is brought to you for free and open access by BYU ScholarsArchive. It has been accepted for inclusion in Theses and Dissertations by an authorized administrator of BYU ScholarsArchive. For more information, please contact scholarsarchive@byu.edu, ellen_amatangelo@byu.edu. 
High School Teachers' Perceptions of Cyber Bullying

Prevention and Intervention Strategies

\author{
Sterling Stauffer
}

A thesis submitted to the faculty of

Brigham Young University

in partial fulfillment of the requirements for the degree of

Educational Specialist

\author{
Melissa Allen Heath, Chair \\ Sarah Coyne \\ Scott Ferrin
}

Department of Counseling Psychology and Special Education

Brigham Young University

August 2011

Copyright $(2011$ Sterling Stauffer

All Rights Reserved 


\author{
ABSTRACT \\ High School Teachers' Perceptions of Cyber Bullying \\ Prevention and Intervention Strategies \\ Sterling Stauffer \\ Department of Counseling Psychology and Special Education, BYU \\ Educational Specialist in School Psychology
}

Results from recent meta-analyses have indicated that bully prevention programs tend to produce little discernable change in student behavior. Possible reasons include a lack of teacher buy-in and teachers' questioning about the effectiveness of such programs. Teacher buy-in is an essential ingredient when implementing and maintaining effective school-based interventions, including bully prevention programs.

In order to examine teachers' perceptions, a questionnaire was administered to 66 high school teachers in a western U.S. urban high school. The questionnaire examined teachers' attitudes regarding the impact of cyber bullying on students; which intervening strategies teachers were likely to use when dealing with cyber bullying; and which prevention strategies would be most helpful in preventing cyber bullying at school.

Descriptive statistics and effect sizes (Cohen's $d$ effect size) were used to describe teachers' perceptions. Based on participants' responses, about $25 \%$ of teachers indicated that cyber bullying does not have long lasting negative effects, and that cyber bullying prepares students for life. When addressing cyber bullying, teachers were most likely to report incidents to administrators, talk to the cyber bully, and talk to the victim. Approximately $42 \%$ of teachers indicated that a formal bully prevention program that addressed cyber bullying should be implemented. Of proposed strategies to decrease cyber bullying, teachers perceived the following strategies as most helpful: increased parental involvement, warning students about consequences for cyber bullying, and increased consequences for cyber bullying.

Administrators are encouraged to survey and consider teachers' perceptions before implementing formal bully prevention programs that target cyber bullying. Additionally, strategies should be considered to foster greater teacher buy-in, thus improving intervention fidelity and ultimately creating a unified effort focused on decreasing student cyber bullying.

Keywords: cyber bullying, teacher buy-in, perceptions, prevention, intervention 


\section{ACKNOWLEDGMENTS}

I would like to give special recognition and thanks to Melissa Allen Heath, without whom I'm convinced this research would never have been completed. For the endless revisions, rewrites, encouragement, support, and 1:00 a.m. emails, she has my profound gratitude. I also want to acknowledge and thank Sarah Coyne and Scott Ferrin for their appreciated input and support.

Greg Hudnall and Cathy Bledsoe also deserve much credit for their contributions in helping with both the design and implementation of this study. I would also like to thank the participants of this study who took the time to offer their opinions and ideas.

My wife, Michelle, deserves recognition as well for her insights and contributions at various points throughout this process. Her love and support have been invaluable to me over the past years. For her I will be forever thankful. 


\section{TABLE OF CONTENTS}

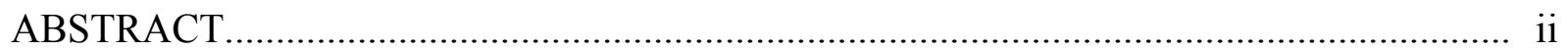

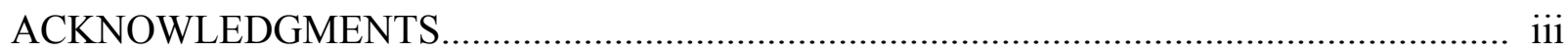

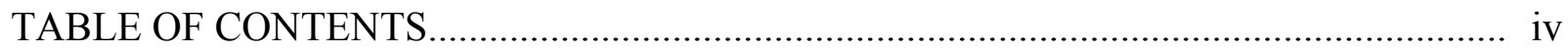

LIST OF TABLES ....................................................................................

DESCRIPTION OF STRUCTURE AND CONTENT ................................................. vi

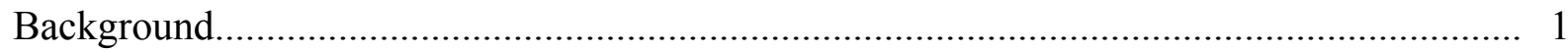

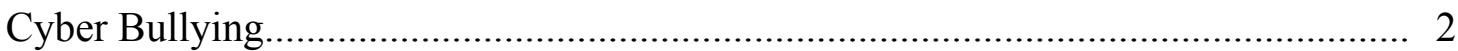

Impact of Bullying and Cyber Bullying ............................................................ 3

School Response to Cyber Bullying.................................................................. 4

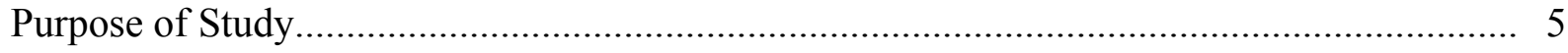

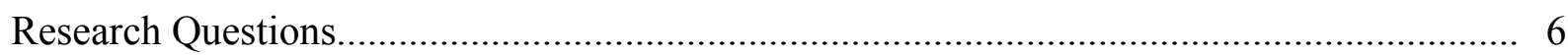

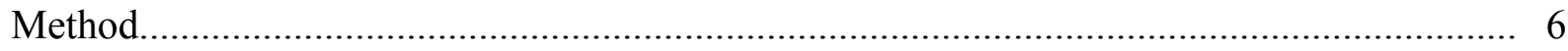

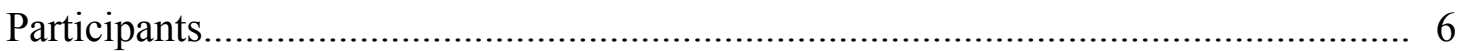

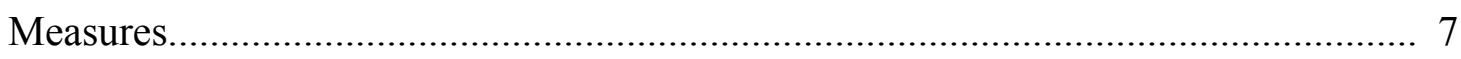

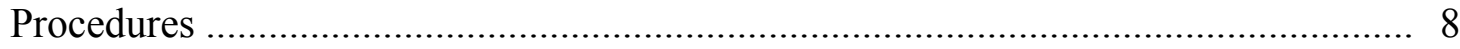

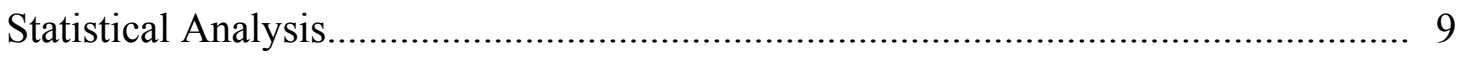

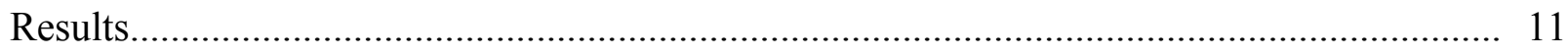

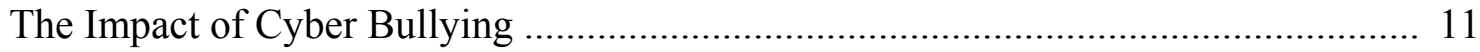

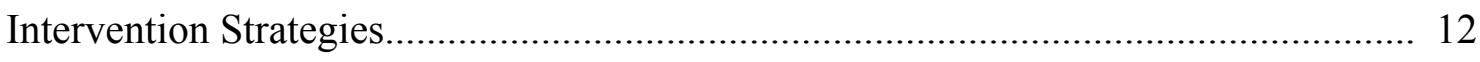

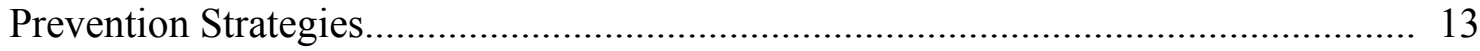

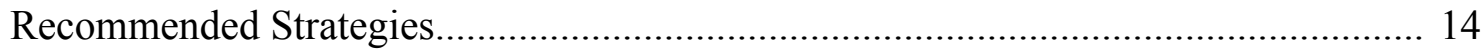

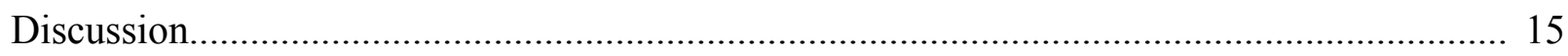

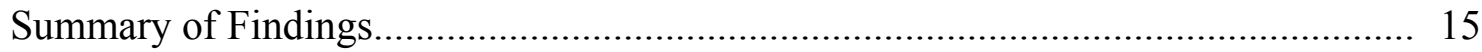

Limitations and Suggestions for Future Research............................................ 17

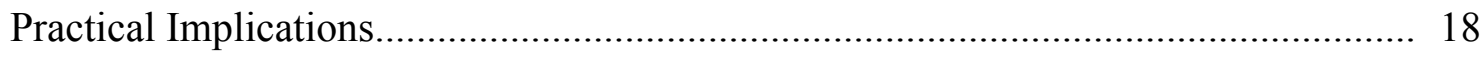

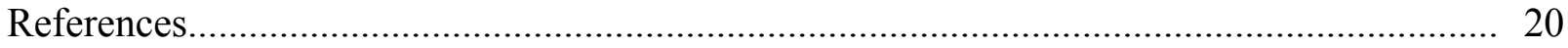

APPENDIX A: REVIEW OF LITERATURE.............................................................. 34

APPENDIX B: Teacher Questionnaire.................................................................... 48

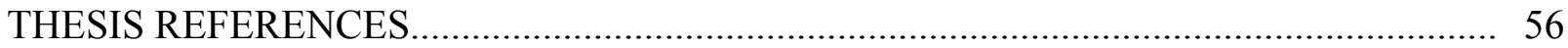




\section{LIST OF TABLES}

1. Research Questions, Survey Questions, and Survey Response Options....................... 25

2. Cyber Bullying's Impact on Students: Percent of Teachers' Responses....................... 27

3. Cyber Bullying's Impact on Students: Descriptive Statistics Summarizing

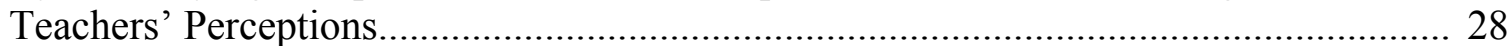

4. Likelihood of Teachers Using Intervening Strategies to Address Cyber Bullying at School.

5. Likelihood of Teachers Using Intervening Strategies to Address Cyber Bullying Away From School.

6. Teachers' Likelihood to Respond to Cyber Bullying at School Versus Away From School...

7. Average Cohen's $d$ Effect Size of Teachers' Perceptions of Bully Prevention Strategies...

8. Teachers' Ideas About What Works to Decrease Cyber Bullying. 


\section{DESCRIPTION OF THESIS STRUCTURE}

Following the introductory pages (title page, acknowledgments, abstract, table of contents, and list of tables), this thesis is segmented into two major sections: (a) the article ready for submission to a journal (pp. 1-34) and (b) the review of the literature (pp. 35-48).

This thesis contains two reference lists. The first reference list (p. 21) contains the references included in the journal-ready article. The second reference list (p. 57) includes all citations used in both the journal-ready article and the section titled "Review of the Literature" (p. 35).

This thesis is prepared in a "submission ready" journal format. A more extensive literature review is included in Appendix A. The Questionnaire that was utilized in this study is included in Appendix B. 


\section{Background}

Holly Grogan was said by her family to be "a wonderful daughter and sister" (Bird, 2009). Her friend described her as having the biggest smile in the world. Tragically, on September 16, 2009, Holly was pronounced dead, a victim of cyber bullying. Holly ended her life by jumping from a 30-foot bridge near Gloucester (UK). Schoolmates had reportedly posted a string of mean-spirited messages on her Internet Facebook page. To distance herself from hateful comments and hoping for a fresh start, Holly moved and switched schools. However, moving did not stop the bullying. A close friend of Holly's told reporters that girls from the old school spread rumors to the new school and the tormenting continued.

Holly Grogan's name joins the growing list of victims who completed suicide to escape relentless cyber bullying. Holly Grogan, Megan Meier, Ryan Halligan, and others have been spotlighted in the media for their tragic experiences involving cyber bullying. However, cyber bullying affects more than the few cases reported in the news.

Beginning with his research in Europe in the 1970s, Dan Olweus brought attention to what was then an unexplored childhood phenomena, bullying. Though bullying prevention in the United States has only been a major area of research since the 1990s, Olweus' work created a wealth of information, building the foundation for what we know about bullying (Berger, 2007). Bullying is defined as intentional aggressive behavior involving an imbalance of power perpetrated repeatedly over time (Olweus, 1993). The imbalance of power may be social or physical. With studies suggesting that 20 to $25 \%$ of children have experienced either physical or emotional bullying in the United States, this is clearly an issue that cannot be ignored by parents or school personnel (Finkelhor, Ormrod, Turner, \& Hamby, 2005; Nansel et al., 2001). In the school setting, teachers, in particular, are in a position of authority, responsible for monitoring 
student behavior, setting classroom rules, reinforcing positive behavior, and imposing disciplinary consequences for inappropriate behavior. For this reason, an understanding of teachers' perceptions is critical in effectively implementing any school-based program that impacts students.

\section{Cyber Bullying}

Due to advancing communication technologies increasingly available to today's youth, a new type of bullying has emerged. Technologies such as the internet, social networking sites, cell phones, texting, and e-mail allow communication to occur at a frequency and speed not previously possible. Adapting to these new modes of communication, cyber bullying has emerged as a new and real danger to students. As Kowalski, Limber, and Agatston (2008) stated in their book titled Cyber Bullying,

Ten years ago, this book wouldn't have been written because no one would have needed it. A decade ago, technology had not advanced to the point where cyber bullying was even an issue .... unfortunately, kids are keeping pace with the changes much more readily than adults. (pp. 41-42)

Self-reported rates of adolescent students who are cyber bullied range from 10\% of students in the United Kingdom (Smith et al., 2008) to 25\% of students in Canada (Li, 2006, 2007). Although research-based rates vary as they do for traditional bullying, most researchers agree that incidents of cyber bullying appear to be on the rise. In schools around the world, cyber bullying negatively impacts students and poses a challenge for school administrators, teachers, and staff (Hinduja \& Patchin, 2010; Kowalski et al., 2008). In particular, schools report difficulty in preparing policy and discipline that identifies cyber bullying and outlines effective responses to cyber bullying (Willard, 2007a, 2007b). 
Though many believe traditional bullying to be the realm of boys while cyber bullying is mainly ruled by girls, studies demonstrate conflicting evidence. While some studies indicate girls are more involved in cyber bullying both as bullies and victims (Kowalski \& Limber, 2007), others report opposite findings (Li, 2006; Slonje \& Smith, 2008). An interesting issue with cyber bullying is that as many as $50 \%$ of victims may not know the identity of their cyber bully, including their gender (Kowalski \& Limber, 2007; Vandebosch \& Van Cleemput, 2007).

Little information exists on the relationship between age and involvement in cyber bullying either as a bully or a victim. While some research suggests that cyber bullying is more common among middle school-aged children than high school students (Slonje \& Smith, 2008), others point to rising involvement in cyber bullying through middle school (Kowalski \& Limber, 2007) with highest prevalence rates among 15-17 year olds (Ybarra \& Mitchell, 2004b).

Although consensus among researchers remains conflicted on the relationship between age and involvement in cyber bullying, it is clear that older students have greater access to technology, including cell phones and the internet, and tend to use it more often (Lenhart, 2009; Lenhart, Madden, \& Hitlin, 2005).

\section{Impact of Bullying and Cyber Bullying}

Numerous studies document bullying's negative impact on students, including reduced academic achievement (Nansel et al., 2001; Rigby, 2003; Smith \& Brain, 2000; Ybarra \& Mitchell, 2004a), anxiety and depression (Rigby, 2003; Ybarra \& Mitchell, 2004a), and school avoidance, particularly for victims (Rigby, 2003; Smith \& Brain, 2000; Ybarra \& Mitchell, 2004a). Although research on the effects of cyber bullying is less extensive than that of traditional bullying, researchers believe the effects of cyber bullying may be similar to or potentially more harmful than traditional bullying (Ybarra \& Mitchell, 2004b). Researchers have 
reported effects ranging from depression and fear (Kowalski et al., 2008; Raskauskas \& Stoltz, 2007) to anger and frustration (Hinduja \& Patchin, 2007, 2010) and, sadly in some cases, suicide (Hinduja \& Patchin, 2010; Kowalski et al., 2008).

\section{School Response to Cyber Bullying}

Due to the negative impact of cyber bullying on students, schools must take action to reduce incidents both inside and outside of school. This becomes a particularly sensitive issue when cyber bullying takes place outside of school yet impacts students across all settings. School administrators must proceed with caution, however, when disciplining for speech that occurs outside of the classroom, ensuring first amendment rights are protected (Willard, 2007a). Because of potential legal issues, it is in both the schools' and the students' best interest to carefully draft and implement preemptive policies and prevention programs aimed at reducing if not eliminating cyber bullying.

Because cyber bullying is a relatively new phenomenon, school administrators may be tempted to simply implement an existing anti-bullying program. However, a recent meta-analytic review by Ferguson, Miguel, Kilburn, and Sanchez (2007) indicated that current anti-bullying programs tend to produce few discernible results over time in student behavior. This study and others indicate the challenge schools face in implementing programs that ultimately reduce bullying (Merrell, Gueldner, Ross, \& Isava, 2008; Smith, Schneider, Smith, \& Ananiadou, 2004). These authors conclude that it is not enough to simply implement a prepackaged program purported to produce results. Rather, in advance of implementing intervention, discussion should occur on how to adapt anti-bullying programs to meet the specific needs and attitudes of the entire school community. Limber (2004) notes that traditional anti-bullying prevention programs may not be effective because parents and educators have lingering doubts about the need for and 
the questionable effectiveness of anti-bullying programs (p. 358). If teachers do not perceive bullying as a problem, school's time and money are wasted when implementing bully prevention programs and associated staff training.

The power of teacher buy-in cannot be underestimated, given the strong research base underlying the importance of teachers supporting interventions that impact students' academic and emotional growth (Biggs, Vernberg, Twemlow, Fonagy, \& Dill, 2008; Forman, Olin, Hoagwood, Crowe, \& Saka, 2009; LaRusso, Romer, \& Selman, 2007). A better approach would be to first gain the support of teachers by educating them about the need for bullying and cyber bullying prevention programs (Hirschstein, Edstrom, Frey, Snell, \& McKenzie, 2007; Payne, Gottfredson, \& Gottfredson, 2006).

\section{Purpose of Study}

As Sassu (2006) suggests, it is insufficient to merely look at an individual's responses to bullying: One must consider the relationship between perceptions and attitudes that underlie individual responses. If the adults in the schools do not see cyber bullying as a problem, or as one worthy of addressing, interventions are not likely to see positive effects. For this reason, the issue of evaluating attitudes and perceptions of those most likely to be involved in the day-to-day problems with cyber bullying - teachers-becomes essential.

Despite recognizing the importance of teachers in prevention of traditional bullying, little research has been conducted to explore their perspectives (Sassu, 2006). While studies show that students see cyber bullying as being just as damaging as traditional bullying (Slonje \& Smith, 2008; Smith et al., 2008), there is an evident lack of research examining teachers' views of cyber bullying. This gap must be addressed in order to know how to more effectively deal with cyber bullying in schools. 
As noted previously, schools may be held legally accountable for failing to respond appropriately to cyber bullying (Kowalski et al., 2008; Willard, 2007a). With this in mind, it is important that teachers, school administrators, and other staff members be prepared to appropriately address cases of cyber bullying when brought to their attention.

This study is only a first step in examining current beliefs and attitudes held by teachers. It is assumed that with a greater understanding of existing attitudes and perceptions, interventions and preventions that are sensitive to these elements will be more effective in receiving support from those whose support is critical. The end goal would be to find strategies to help lower instances of cyber bullying both inside school and outside of school. However, before determining how we get there, it is helpful to first determine where we are. That determination is the main focus of this study.

\section{Research Questions}

1. What are teachers' general attitudes regarding the impact of cyber bullying on students?

2. When addressing cyber bullying, which intervening strategies are teachers most likely to use?

3. Based on teacher perceptions, how effective are specific prevention strategies in decreasing cyber bullying?

\section{Participants}

\section{Method}

Research was conducted in an urban high school in the Western United States. Of the 105 potential high school teachers who were invited to participate, 66 teachers completed an online survey (63\% participation rate). Of these participants, $59 \%$ were male and $41 \%$ were female. Thirty-nine percent of participants reported their highest level of education as a bachelor's degree; $53 \%$ reported a master's degree; 1 teacher $(2 \%)$ reported a specialist degree; $1(2 \%)$ 
reported a doctorate, and 2 (4\%) responded "other." As reflected in their responses, several teachers worked with students in both general education and special education. Ninety-one percent of participants reported working with students in general education classrooms; $27 \%$ reported working in special education classrooms, and $8 \%$ reported working in "Youth in Custody" programs. On average, participants taught for 15.5 years $(S D=9.27)$, with an average of 11.5 years $(S D=8.34)$ in the current school district.

During the year in which the study was conducted, the high school served over 1,800 students from grades $9-12$. The participating school's ethnic makeup was: undeclared $(0.32 \%)$, Native American (1.18\%), Black (1.34\%), Asian (1.77\%), Pacific Islander (2.42\%), Hispanic (25.18\%), and White (67.76\%).

Approximately $35 \%$ of students attending the school qualified for free lunch; $11 \%$ qualified for reduced lunch, totaling $46 \%$ of students receiving free or reduced-price lunch (FRPL). Nationally, schools with 76-100\% of students receiving FRPL are considered high poverty schools and those with $0-25 \%$ of students receiving FRPL are considered low poverty schools (U.S. National Center for Education Statistics [NCES], 2010). Economically, the participating school's population was in the middle portion of all schools nationwide (not considered a high or low poverty school).

\section{Measures}

A questionnaire was designed by a school district administrator and the primary author. The questionnaire was refined based on feedback from a small group of school psychology graduate students, a school psychology professor, and a public school teacher. The measure was part of a larger study conducted by the school district to determine teachers' overall perceptions and attitudes in regards to bullying, with cyber bullying as a targeted subset of bullying 
behaviors. The questionnaire evaluated several facets of cyber bullying, including teachers' perceptions of the severity of cyber bullying in schools, the effect of cyber bullying on victims, where cyber bullying occurs, the perceived need for prevention programs, the effectiveness of prevention strategies, and the likelihood of intervening with a variety of intervention strategies. The majority of questions' response options utilized a five-point Likert scale. The remaining three questions were open ended, exploring teachers' perceptions of difficulties in addressing cyber bullying and teachers' perceptions of what works in decreasing cyber bullying.

In order to describe participating teachers, six demographic questions were also included. These questions asked participants to designate their gender, number of years working as a teacher, number of years working in current school district, highest level of education, grade level of students taught or supervised, and whether students were identified as general education, special education, and/or youth in custody/adjudicated youth. Research questions, survey questions corresponding to research questions, and response options to the survey questions are included in Table 1. A copy of the questionnaire is available upon request from the primary author.

\section{Procedures}

The questionnaire was encoded into Qualtrics, an online survey creation and distribution package. The questionnaire was tested for approximate length and encoding errors. An Internet link was then created by Qualtrics and e-mailed by district supervisors to the principal of the participating school. During a school faculty meeting, teachers were encouraged to complete this study's survey, described as a survey on the topic of bullying and cyber bulling. The purpose for the survey was explained to potential participants as helping the school district better define 
what happens in schools in regards to cyber bullying. The participants were also given some general instructions in regard to taking the survey. Teachers were then offered the choice of either taking a 20 minute break or utilizing that time to complete the online survey.

\section{Statistical Analysis}

Descriptive statistics (percentages, sum totals, range, means, and standard deviations) were used to summarize quantitative data. In addition to descriptive statistics, questions that examined teachers' perceptions of what would be helpful in reducing cyber bullying and teachers' likely responses to cyber bullying were compared within comparable sections by analyzing effect sizes and comparing mean differences with the overall mean for each grouping of questions (analysis of variance). A conservative level of statistical significance was set for each analysis $(p \leq .01)$

Effect size measures the extent to which two or more results vary from each other (Cohen, 1994) and have been recommended by the American Psychological Association (APA) for use in psychological research (Wilkinson \& Task Force on Statistical Inference, 1999). Specifically a Cohen's $d$ effect size was used in this study's data analysis to describe differences between similar groups of item responses. A Cohen's $d$ is calculated by subtracting the mean score of one survey response item from the pooled mean for the group of similar survey responses. This difference is then divided by the average pooled standard deviation for the group of similar survey items. A negative effect size $d$ indicates that the mean for a specific survey item was greater than that of the group mean, whereas a positive effect size indicates that the mean for a specific survey item was less than that of the overall group mean.

In the context of this study, a negative effect size indicates a more helpful intervention or prevention strategy (higher mean), with a positive effect size indicating a less helpful 
intervention or prevention strategy (lower mean). According to Cohen (1988), a resulting $d$ of approximately .2 is considered a small effect size (a small difference), while an effect size of approximately .5 is considered a medium effect size (medium difference), and .8 is considered a large effect size (large difference). Though Cohen cautioned that these standard limits should compare data with previous research findings, the lack of similar studies prohibits such comparison in the present study. It should be mentioned that even though results may not meet the small effect size criteria of .2, even small differences (as evidenced in $\leq .2$ effects sizes) may be noteworthy, depending on the implication of a small difference. In other words, effect size differences must be interpreted with caution and in the context of what even a small difference may mean for individuals and groups. For a brief review of research-based effect sizes, see Thompson (2007). Additionally, descriptive data should be interpreted based on Likert scale anchor point descriptions (e.g., $0=$ Very Unlikely; $1=$ Unlikely; $2=$ Undecided; $3=$ Likely; $4=$ Very Likely).

Participants' responses to one open-ended survey question were analyzed for common themes relating to this study's research questions. The first author and one co-author discussed participant's comments and identified overarching themes (coding categories). Responses were then independently coded, disagreements discussed and resolved by further discussion, and interrater reliability determined (above 90\% agreement across coding categories). Comments were summarized (descriptive statistics included summed totals and percentages). Specific responses that succinctly described points of interest were quoted. Identifying information was removed to ensure participants' confidentiality. 


\section{Results}

After completing their surveys, teachers' data were summarized and analyzed. Based on the data, the following information is presented to answer this study's research questions.

\section{The Impact of Cyber Bullying}

The first research question investigated teachers' general attitudes regarding the impact of cyber bullying on students. In general, participants indicated that cyber bullying does not "toughen kids up," has long lasting negative effects on students, and does not "prepare students for life." Though the majority of teachers' attitudes and perceptions reflect what we would hope to see among teachers, up to one-fourth of teachers did not endorse socially desirable responses. These teachers were either neutral or they strongly agreed with perceptions that countered desired attitudes.

For example, $18 \%$ of participants indicated that they were neutral to or agreed with the statement, "cyber bullying toughens kids up." About 25\% of participants reported that they were neutral to or disagreed with the statement, "cyber bullying has long lasting negative effects." The same percentage indicated they were either neutral to or agreed with the statement that cyber bullying "prepares students for life" (see Table 2).

Table 3 includes descriptive statistics summarizing teachers' perceptions of cyber bullying's impact on students. When asked the extent to which they agreed with the statement, “cyber bullying toughens kids up," the median response was Strongly Disagree $(M=0.68$, Median $=0, S D=.89$ ). The median response to the statement, "cyber bullying has long lasting negative effects," was Agree $(M=2.99$, Median $=3, S D=1.05)$. Participants' median response to, "cyber bullying prepares students for life," was Disagree $(M=0.91$, Median $=1, S D=.95)$. 
When asked if a formal bully prevention program should be implemented in the school, only $9 \%$ were not supportive, indicating definitely not or probably not. Almost half of all teachers $(49 \%)$ were unsure about implementing a formal bullying program, indicating a program should maybe be implemented. The remaining teachers $(42 \%)$ indicated that a prevention program should probably or definitely be implemented.

\section{Intervention Strategies}

The second research question investigated the likelihood of teachers intervening with specific strategies to address cyber bullying. Mean scores indicated that teachers were somewhere between Undecided and Likely to use all of the suggested strategies with the exception of "Do nothing." When aware of cyber bullying occurring at school, teachers reported that they were very unlikely $(d=.93)$ to do nothing. Because none of the options in this cluster of options were strongly endorsed, these results indicate that although teachers are inclined to respond to cyber bullying, they may be unsure as to how they should or would respond. Results summarizing teachers' responses are summarized in Tables 4 (cyber bullying occurring at school) and 5 (cyber bullying occurring away from school).

However, in evaluating which strategies stand out from the others, teachers reported that when aware of cyber bullying occurring at school, they were more likely to report the incident to school administrators. Additionally, teachers were somewhat likely to talk to the cyber bully and the victim. Teachers also indicated they were somewhat likely to take away the cyber bully's privileges. In looking at what teachers would do, the strongest effect size was associated with "Report incident to school administrators" $(d=-.50)$. Small effect sizes were found for "Talk with the cyber bully" $(d=-.20)$ and "Talk with the victim" $(d=-.31)$. 
Average responses when the cyber bullying occurred away from school indicated that teachers were on average more undecided about their likelihood to use the listed strategies. Teachers reported being somewhat unlikely to "Do nothing" $(d=.24)$, indicating they were more likely to ignore the cyber bullying if it occurred away from school. In similar contrast, whereas participants were somewhat likely to take away privileges of cyber bullies if it occurred at school, they reported being somewhat unlikely $(d=.24)$ to take away privileges if the incident occurred away from school. In essence, it appears that teachers see themselves as having little or no responsibility to intervene if the cyber bullying occurs away from school. They did report, however, that they would be somewhat likely to "Talk with the victim" ( $d=-.19)$, as well as "Report incident to school administrators" $(d=-.29)$.

In comparing teachers' responses based on cyber bullying occurring either at school or away from school, paired t-tests indicated that teachers were much more likely to endorse responses to cyber bullying at school. The only comparison not reaching statistical significance was "do nothing" $(p=.092)$. Teachers were the least likely to endorse this response, regardless if the cyber bullying occurred at or away from school. Paired $t$-test results are summarized in Table 6.

\section{Prevention Strategies}

The third research question investigated teachers' perceptions of the effectiveness of specific prevention strategies in decreasing cyber bullying. Table 7 summarizes teachers' responses to this question. When asked to share their ideas about what works to decrease cyber bullying, the majority of teachers' responses dealt with prevention. Participants were asked if they believed a formal bully prevention program should be implemented. In response, $42 \%$ of participants reported a need for this type of prevention program. More importantly, however, 
$49 \%$ indicated that they were unsure about implementing a formal program, while the remaining $9 \%$ of participants indicated that a formal bully prevention program should not be implemented in their school.

There are several ways that this item could be interpreted. Perhaps teachers feel unsure about the effectiveness of bully prevention programs, and are resistant to or unsure about implementing another program. It is also possible that teachers are not aware of bullying or cyber bullying problems at their school, and are not against bully prevention programs in general, but are unsure regarding the actual need for this type of program for their students.

Teachers were also asked to rate the helpfulness of different bully prevention strategies. The average score on most items indicated that teachers overall felt that all of the items were at least somewhat helpful. However, of the 11 strategies which have been suggested by different researchers either for cyber bully or bully prevention, only 3 had a Cohen's $d$ value $\geq .2$ and were perceived as more helpful when compared to other possible responses. Teachers perceived "Increased parental involvement" ( $d=-.59)$, "Warn about consequences for cyber bullying" $(d=$ -.23), and "Increased consequences for cyber bullying" ( $d=-.38)$ as more helpful in decreasing cyber bullying.

In rating the helpfulness of different bully prevention strategies, some strategies were seen as less helpful. These included: "School-wide anti-bully assemblies" $(d=.32)$, "Establish a school bullying task force to develop anti-bullying policies" ( $d=.22)$, "Classroom anti-bully lessons" ( $d=.29)$, and "Professional development teacher seminars" $(d=.30)$.

\section{Recommended Strategies}

Teachers were given the option of sharing their ideas about what works to decrease cyber bullying. Table 8 summarizes teachers' responses to the following open ended request for 
additional information: "Share your ideas about what works to decrease cyber bullying." Of the 66 participating high school teachers, 39 (59\%) provided a response to the question of what works to reduce cyber bullying. Of these 39 teachers' responses, approximately $30 \%$ supported educating students about the consequences of cyber bullying and how students should respond to cyber bullying. Approximately $22 \%$ of teachers' responses addressed limiting student access to electronic devices at school and at home. In addition, 7.5\% of comments recommended increased parental support as an effective deterrent to cyber bullying. Only $7 \%$ of teachers' responses recommended direct school-based interventions. These recommendations were generally vague such as, "Punish cyber bully," or "Strong consequences."

\section{Discussion}

This study was conducted to describe high school teachers' perceptions of cyber bullying prevention and intervention strategies. More specifically 66 high school teachers responded to questions regarding the impact of cyber bullying on students, intervening strategies teachers would most likely use, and the effectiveness of specific prevention strategies in decreasing cyber bullying. A summary of the findings will be reviewed, followed by limitations of the current study and suggestions for future research, and concluding with recommendations for educators.

\section{Summary of Findings}

The first question of this study investigated teachers' general attitudes regarding the impact of cyber bullying on students. Most teachers indicated that cyber bullying has long lasting negative effects, and that it does not "toughen kids up." However, up to one of every four teachers indicated being neutral about or disagreeing about cyber bullying having long lasting negative effects, as well as being neutral or agreeing that cyber bullying "prepares students for 
life." Nearly $60 \%$ of teachers were either unsure about or against implementing a formal bullying prevention program in their school.

It is possible that some participants simply didn't see bullying as a problem at their school, or they were unsure about the effectiveness of a formal prevention program. It is also possible that teachers see a "formal" prevention program as going too far, or being unnecessary where equal results might be obtained with more "informal" measures. Whatever the case, evaluating teachers' perceptions prior to implementing a school-wide program appears to be an important prerequisite. If over half of the teachers at a given school are unsure about or against implementing a school-wide program, treatment integrity would be jeopardized and potential impact substantially negated.

The next question investigated the types of strategies teachers use when they witness or are made aware of cyber bullying. When the cyber bullying occurred at school, teachers reported being most likely to report to school administrators. They also indicated being somewhat likely to talk with the cyber bully or the victim and to take away the bully's privileges. When cyber bullying occurs away from school, however, teachers reported being only somewhat likely to talk with the victim or report the incident to administrators. In comparison to other possible intervening strategies, either implemented at school or away from school, teachers did not indicate a propensity to report cyber bullying incidents to parents.

It is possible that teachers do not see it as their responsibility to intervene in response to cyber bullying other than to report the incident to administrators. This becomes especially apparent when the cyber bullying occurs away from school. Teachers may also be apprehensive about parental retaliation for intervening with behaviors that don't occur specifically at school. 
The final question assessed which prevention activities or strategies would be most helpful in reducing cyber bullying. Teachers indicated increased parental involvement as the most helpful prevention strategy, followed by "increased consequences for cyber bullying," and "warn about consequences for cyber bullying." They perceived school-wide anti-bully assemblies and classroom anti-bully lessons as being somewhat less helpful than other strategies, perhaps indicating a belief that students should be warned about increased consequences by parents, and not by school teachers and administrators.

\section{Limitations and Suggestions for Future Research}

Because this study was conducted in one high school and with a relatively small number of participants, caution should be used when generalizing findings to other populations and age groups. Similar to this participating school, other schools should conduct their own research study to assess teachers' perceptions of cyber bulling. Findings would be unique to each school's

specific population of students and community demographics (i.e., religious, socioeconomic, and racial). Although some findings may be consistent across settings, each school would benefit from conducting their own survey of teachers' perceptions.

It is possible that teachers may have understood survey item questions differently, or that the wording may have been confusing. For example, when asked "When aware of students' cyber bullying away from school, how likely are you to take the following actions?" teachers may have understood the question to ask what they would do if the cyber bullying occurred away from school, or what they would do if the teachers became aware of the cyber bullying while they were not at school. This possible ambiguity may have lead teachers to answer the question differently, thereby confounding interpretation. 
Teachers noted that they were likely to report cyber bullying to administrators, but it is unclear what action would then be taken by the administrators. Additional studies examining what happens when incidents of cyber bullying are reported to administrators would help further describe the current situation in schools.

Additionally, the number of participants prohibited the use of more extensive statistical measures such as MANOVA which could have more extensively investigated research questions and relationships among research variables. Though the current study had a solid participation rate $(63 \%)$, it is possible that the results were skewed because of a self-selection bias, meaning that teachers who chose to participate may have held different perceptions than those who chose not to participate. No analysis was conducted to determine why some teachers chose not to participate. It is possible that nonparticipants had faced negative or even traumatic experiences in the past involving cyber bullying. Random selection of participants and an analysis of nonparticipants in future studies might minimize these risks.

\section{Practical Implications}

Some practical recommendations for guiding educators emerged from this study. The first is that while many participants indicated that cyber bullying was detrimental to students, almost one-fourth of teachers were less convinced of cyber bullying's negative impact on students. In addition, nearly $60 \%$ of participants were unsure about the need for a formal bully prevention program. An evaluation of teachers' perceptions would inform administrators about the potential barriers and lack of teacher buy-in prior to implementing a bully prevention program. Teachers' perceptions should be considered when administrators plan and prepare information about bullying and make decisions regarding the type of strategies to address bullying problems. 
Second, while teachers indicated that reporting incidents of cyber bullying to administrators was helpful, participants were not likely to report the incident to parents of the cyber bully or the victim, regardless of where the cyber bullying occurred (home or school). The importance of parental involvement in preventing cyber bullying cannot be ignored. Multiple studies have indicated that students are more likely to cyber bully others when there is a lack of parental monitoring of online activities (Vandebosch \& Van Cleemput, 2007; Ybarra \& Mitchell, 2004b). If the parents are not aware of the cyber bullying, they are not likely to intervene in meaningful ways to prevent further involvement. All educators need to understand the importance of reporting cases of cyber bullying not only to administrators, but also to parents.

Third, while teachers indicated that teaching students about the consequences of cyber bullying and strategies to deal with cyber bullies were effective prevention strategies, they did not perceive classroom lessons or assemblies (presumably where these strategies would be taught) as helpful. It is possible that teachers see addressing cyber bullying as "not my responsibility," but as a responsibility of school administrators and parents. Policy makers and administrators should be aware of these perceptions and determine ways to help shift teachers' opinions and better equip teachers to take a more active role in monitoring student cyber bulling and intervening with cyber bullying incidents. In addition, teachers may be more receptive to anti-bullying programs that share responsibility by addressing cyber bullying at both school and community levels, rather than solely in the classroom. 


\section{References}

Berger, K. S. (2007). Update on bullying at school: Science forgotten? Developmental Review, 27(1), 90-126.

Biggs, B. K., Vernberg, E. M., Twemlow, S. W., Fonagy, P., \& Dill, E. J. (2008). Teacher adherence and its relation to teacher attitudes and student outcomes in an elementary school-based violence prevention program. School Psychology Review, 37(4), 533-549.

Bird, S. (2009). Holly Grogan, 15, leapt to her death 'after abuse from Facebook bullies.' The Times. Retrieved from http://www.timesonline.co.uk/tol/news/uk/article6841908.ece

Cohen, J. (1988). Statistical power analysis for the behavioral sciences (2nd ed.). Hillsdale, NJ: Erlbaum.

Cohen, J. (1994). The earth is round (p .05). American Psychologist, 49, 997-1003.

Ferguson, C. J., Miguel, C. S., Kilburn, J. C., \& Sanchez, P. (2007). The effectiveness of schoolbased anti-bullying programs: A meta-analytic review. Criminal Justice Review, 32(4), 401-414.

Finkelhor, D., Ormrod, R., Turner, H., \& Hamby, S. L. (2005). The victimization of children and youth: A comprehensive, national survey. Child Maltreatment, 10, 5-25.

Forman, S. G., Olin, S. S., Hoagwood, K. E., Crowe, M., \& Saka, N. (2009). Evidence-based interventions in schools: Developers' views of implementation barriers and facilitators. School Mental Health, 1(1), 26--36.

Hirschstein, M. K., Edstrom, L.V.S., Frey, K. S., Snell, J. L., \& MacKenzie, E. P. (2007). Walking the talk in bullying prevention: Teacher implementation variables related to initial impact of the Steps to Respect program. School Psychology Review, 36(1), 3-21. 
Hinduja, S., \& Patchin, J. W. (2007). Offline consequences of online victimization: School violence and delinquency. Journal of School Violence, 6(3), 89-112.

Hinduja, S., \& Patchin, J. W. (2010). Bullying, cyberbullying, and suicide. Archives of Suicide Research, 14, 206-221.

Kowalski, R. M., \& Limber, S. P. (2007). Electronic bullying among middle school students. Journal of Adolescent Health, 41, 22-30.

Kowalski, R. M., Limber, S. P., \& Agatston, P. W. (2008). Cyber Bullying: Bullying in the digital age. Malden, MA: Blackwell Publishing.

LaRusso, M. D., Romer, D., \& Selman, R. L. (2007). Teachers as builders of respectful school climates: Implications for adolescent drug use norms and depressive symptoms in high school. Journal of Youth and Adolescence, 37(4), 386-398.

Lenhart, A., Madden, M., \& Hitlin, P. (2005). Teens and technology. Retrieved from http://www.pewinternet.org/Reports/2005/Teens-and-Technology.aspx

Lenhart, A. (2009). Teens and mobile phones over the past five years: PEW Internet looks back. Retrieved from http://www.pewinternet.org/Reports/2009/14--Teens-and-Mobile-PhonesData-Memo.aspx

Limber, S. P. (2004). Implementation of the Olweus Bullying Prevention Program in American schools: Lessons learned from the field. In D. L. Espelage \& S. M. Swearer (Eds.), Bullying in American schools: A social-ecological perspective on prevention and intervention (pp. 351-363). Mahwah, NJ: Lawrence Erlbaum.

Li, Q. (2006). Cyber bullying in schools: A research of gender differences. School Psychology International, 27(2), 157-170. 
Li, Q. (2007). New bottle but old wine: A research of cyberbullying in schools. Computers in Human Behavior, 23, 1777-1791.

Merrell, K. W., Gueldner, B. A., Ross, S. W., \& Isava, D. M. (2008). How effective are school bullying intervention programs? A meta-analysis of intervention research. School Psychology Quarterly, 23(1), 26-42.

Nansel, T. R., Overpeck, M. D., Pilla, R. S., Ruan, W. J., Simmons-Morton, B., \& Scheidt, P. (2001). Bullying behavior among U.S. youth: Prevalence and association with psychosocial adjustment. Journal of the American Medical Association, 285, 2094-2100.

Olweus, D. (1993). Bullying at school: What we know and what we can do. Cambridge, MA: Blackwell.

Payne, A., Gottfredson, D. C., \& Gottfredson, G. D. (2006). School predictors of the intensity of implementation of school-based prevention programs: Results from a national study. Prevention Science, 7, 225-237.

Raskauskas, J., \& Stoltz, A.D. (2007). Involvement in traditional and electronic bullying among adolescents. Developmental Psychology, 43(3), 564-575.

Rigby, K. (2003). Consequences of bullying in schools. The Canadian Journal of Psychiatry/La Revue Canadienne de Psychiatrie, 48(9), 583-590.

Sassu, K. A. (2006). Teachers' perceptions of bullying: An investigation of reported characteristic behaviors and the likelihood of intervention in response to overtly and relationally aggressive behavior (Doctoral dissertation, University of Connecticut). Retrieved from http://digitalcommons.uconn.edu/dissertations/AAI3205760

Slonje, R., \& Smith, P. K. (2008). Cyberbullying: Another main type of bullying? Scandinavian Journal of Psychology, 49, 147-154. 
Smith, J. D., Schneider, B. H., Smith, P. K., \& Ananiadou, K. (2004). The effectiveness of whole-school anti-bullying programs: A synthesis of evaluation research. School Psychology Review, 33 (4), 547-560.

Smith, P. K., \& Brain, P. (2000). Bullying in schools: Lessons from two decades of research. Aggressive Behavior, 26, 1-9.

Smith, P. K., Mahdavi, J., Carvalho, M., Fisher, S., Russell, S., \& Tippett, N. (2008). Cyberbullying: Its nature and impact in secondary schools. Journal of Child Psychology and Psychiatry, 49(4), 376-385.

Thompson, B. (2007). Effect sizes, confidence intervals, and confidence intervals for effect sizes. Psychology in the Schools, 44(5), 423-432.

United States Department of Education, National Center for Education Statistics. (2010). Special analysis 2010: High poverty public schools. Retrieved from http://nces.ed.gov/programs/coe/2010/analysis/index.asp

Vandebosch, H., \& Van Cleemput, K. (2007). Cyber bullying among youngsters. Conference Papers -- International Communication Association. Retrieved from Communication \& Mass Media Complete database.

Willard, N. E. (2007a). The authority and responsibility of school officials in responding to cyberbullying. Journal of Adolescent Health, 41, 64-65.

Willard, N. E. (2007b). Educator's guide to cyberbullying: Addressing the harm caused by online social cruelty. Retrieved from http://www.asdk12.org/MiddleLink/AVB/bully_topics/EducatorsGuide_Cyberbullying.p df 
Wilkinson, L., \& Task Force on Statistical Inference, American Psychological Association, Science Directorate. (1999). Statistical methods in psychology journals: Guidelines and explanations. American Psychologist, 54, 594-604.

Ybarra, M. L., \& Mitchell, K. J. (2004a). Youth engaging in online harassment: Associations with caregiver-child relationships, Internet use, and personal characteristics. Journal of Adolescence, 27, 319-336.

Ybarra, M. L., \& Mitchell, K. J. (2004b). Online aggressor/targets, aggressors, and targets: A comparison of associated characteristics. Journal of Child Psychology and Psychiatry, 45(7), $1308-1316$. 
Table 1

Research Questions, Survey Questions, and Survey Response Options

\begin{tabular}{|c|c|c|}
\hline Research questions & Survey questions & Response options \\
\hline \multirow[t]{2}{*}{$\begin{array}{l}\text { 1. What are teachers' } \\
\text { general attitudes } \\
\text { regarding the impact of } \\
\text { cyber bullying on } \\
\text { students? }\end{array}$} & $\begin{array}{l}\text { To what extent do you agree with the } \\
\text { following statements? } \\
\text { - Cyber bullying toughens kids up } \\
\text { - Cyber bullying has long lasting negative } \\
\text { - } \quad \text { Cyfects } \\
\text { - Cyber bullying prepares students for life }\end{array}$ & $\begin{array}{l}0=\text { Strongly Disagree } \\
1=\text { Disagree } \\
2=\text { Neutral } \\
3=\text { Agree } \\
4=\text { Strongly Agree }\end{array}$ \\
\hline & $\begin{array}{l}\text { Should a formal bully prevention program be } \\
\text { implemented in your school? }\end{array}$ & $\begin{array}{l}0=\text { Definitely not } \\
1=\text { Probably not } \\
2=\text { Maybe } \\
3=\text { Probably yes } \\
4=\text { Definitely yes }\end{array}$ \\
\hline \multirow[t]{3}{*}{$\begin{array}{l}\text { 2. When addressing } \\
\text { cyber bullying, which } \\
\text { intervening strategies } \\
\text { are teachers most likely } \\
\text { to use? }\end{array}$} & $\begin{array}{l}\text { When aware of students' cyber bullying at } \\
\text { your school, how likely are you to take the } \\
\text { following actions? } \\
\text { - Do nothing } \\
\text { - Talk with the cyber bully } \\
\text { - Talk with the victim } \\
\text { - Take away cyber bully's privileges } \\
\text { - Mediate / Problem solve with cyber bully } \\
\text { - } \text { and victim } \\
\text { - Report incident to cyber bully's parents } \\
\text { - Report incident to victim's parents } \\
\text { - Other (specify) }\end{array}$ & $\begin{array}{l}0=\text { Very Unlikely } \\
1=\text { Unlikely } \\
2=\text { Undecided } \\
3=\text { Likely } \\
4=\text { Very Likely }\end{array}$ \\
\hline & $\begin{array}{l}\text { When aware of students' cyber bullying away } \\
\text { from school, how likely are you to take the } \\
\text { following actions? } \\
\text { (Same actions as \#1) }\end{array}$ & $\begin{array}{l}0=\text { Very Unlikely } \\
1=\text { Unlikely } \\
2=\text { Undecided } \\
3=\text { Likely } \\
4=\text { Very Likely }\end{array}$ \\
\hline & $\begin{array}{l}\text { Share your ideas about what works to } \\
\text { decrease cyber bullying. }\end{array}$ & Open ended \\
\hline
\end{tabular}


Table 1

Research Questions, Survey Questions, and Survey Response Options (continued)

\begin{tabular}{|c|c|c|}
\hline Research questions & Survey questions & Response options \\
\hline \multirow[t]{3}{*}{$\begin{array}{l}\text { 3. Based on teacher } \\
\text { perceptions, how } \\
\text { effective are specific } \\
\text { prevention strategies in } \\
\text { decreasing cyber } \\
\text { bullying? }\end{array}$} & $\begin{array}{l}\text { Should a formal bully prevention program } \\
\text { be implemented in your school? }\end{array}$ & $\begin{array}{l}0=\text { Definitely not } \\
1=\text { Probably not } \\
2=\text { Maybe } \\
3=\text { Probably yes } \\
4=\text { Definitely yes }\end{array}$ \\
\hline & $\begin{array}{l}\text { How helpful would these bully prevention } \\
\text { strategies be in reducing cyber bullying at } \\
\text { your school? } \\
\text { - Increased supervision in certain areas } \\
\text { - } \quad \text { More specific school policies } \\
\text { - } \quad \text { School-wide anti-bully assemblies } \\
\text { - } \quad \text { Facilitate school climate encouraging } \\
\text { - } \text { students to report cyber bullying } \\
\text { Establish a school bullying task force to } \\
\text { - } \text { develop anti-bullying policies } \\
\text { - } \text { against cyber bullies } \\
\text { - Professional development teacher } \\
\text { - } \text { Incminars } \\
\text { - } \text { bullying } \\
\text { Warn about consequences for cyber } \\
\text { bullying } \\
\text { - } \text { Othcreased parental involvement }\end{array}$ & $\begin{array}{l}0=\text { Not helpful } \\
1=\text { Slightly helpful } \\
2=\text { Somewhat helpful } \\
3=\text { Helpful } \\
4=\text { Very helpful }\end{array}$ \\
\hline & $\begin{array}{l}\text { Share your ideas about what works to } \\
\text { decrease cyber bullying. }\end{array}$ & Open ended \\
\hline
\end{tabular}


Table 2

Cyber Bullying's Impact on Students: Percent of Teachers' Responses

\begin{tabular}{|c|c|c|c|}
\hline \multirow[b]{2}{*}{ Statement } & \multicolumn{3}{|c|}{ Percent of teachers' responses } \\
\hline & $\begin{array}{c}\text { Agree or } \\
\text { Strongly } \\
\text { Agree }\end{array}$ & Neutral & $\begin{array}{c}\text { Disagree or } \\
\text { Strongly } \\
\text { Disagree }\end{array}$ \\
\hline Cyber bullying toughens kids up & 4.62 & 13.85 & 81.54 \\
\hline $\begin{array}{l}\text { Cyber bullying has long lasting negative } \\
\text { effects }\end{array}$ & 75.38 & 18.46 & 6.15 \\
\hline Cyber bullying prepares students for life & 7.69 & 16.92 & 75.38 \\
\hline
\end{tabular}


Table 3

Cyber Bullying's Impact on Students: Descriptive Statistics Summarizing Teachers' Perceptions To what extent do you agree with the following statements?

Cyber bullying toughens kids up $M$ Median $S D$

Cyber bullying has long lasting negative effects 2.99 0 .89

Cyber bullying prepares students for life 0.91 3 1.05 0.68

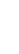

Note. $N=66$.

Response options: $0=$ Strongly Disagree; 1= Disagree; 2= Neutral; 3=Agree; 4= Strongly Agree 
Table 4

Likelihood of Teachers Using Intervening Strategies to Address Cyber Bullying at School

When aware of students' cyber

bullying at your school, how

likely are you to take the

$M(S D) \quad \underset{(2-t a i l e d)}{p^{\mathrm{a}}} \quad$ Cohen's $d^{\mathrm{b}} \quad$ Interpretation

following actions?

$\begin{array}{llrrr}\text { Do nothing } & 1.60(1.18) & <.001 & .93 & \text { Very unlikely } \\ \begin{array}{l}\text { Talk with the cyber bully } \\ \text { Talk with the victim }\end{array} & 2.72(.84) & .068 & -.20 & \text { Somewhat likely } \\ \begin{array}{l}\text { Take away cyber bully's } \\ \text { privileges }\end{array} & 2.81(.78) & .005 & -.31 & \text { Somewhat likely } \\ \begin{array}{l}\text { Mediate / Problem solve with } \\ \text { cyber bully and victim }\end{array} & 2.70(.94) & .157 & -.19 & \text { Somewhat likely } \\ \begin{array}{l}\text { Report incident to cyber bully's } \\ \text { parents }\end{array} & 2.46(.84) & .510 & .06 & \\ \begin{array}{l}\text { Report incident to victim's } \\ \text { parents }\end{array} & 2.41(.85) & .253 & .09 & -.09 \\ \begin{array}{l}\text { Report incident to school } \\ \text { administrators }\end{array} & 2.99(.84) & <.001 & -.50 & \text { Likely } \\ \end{array}$

Note. Response options: $0=$ Very Unlikely; 1=Unlikely; 2=Undecided; $3=$ Likely; $4=$ Very Likely

${ }^{a} p$ values are based on comparisons made between the overall mean for this group of questions $(M=2.5307)$ and the mean for the specific responses to each question.

${ }^{\mathrm{b}}$ Absolute Value of Cohen's $d \geq .2=$ Small; $\geq .5=$ Medium; $\geq .8=$ Large 
Table 5

Likelihood of Teachers Using Intervening Strategies to Address Cyber Bullying Away From School

When aware of students' cyber bullying away from school, how likely are you to take the $M(S D) \quad \begin{gathered}p^{\mathrm{a}} \\ \text { (2-tailed) }\end{gathered} \quad$ Cohen's $d^{\mathrm{b}} \quad$ Interpretation following actions?

\begin{tabular}{llccc}
\hline $\begin{array}{l}\text { Do nothing } \\
\text { Talk with the cyber bully }\end{array}$ & $1.81(1.14)$ & .084 & .24 & $\begin{array}{c}\text { Somewhat } \\
\text { unlikely }\end{array}$ \\
$\begin{array}{l}\text { Talk with the victim } \\
\begin{array}{l}\text { Take away cyber bully's } \\
\text { privileges }\end{array}\end{array}$ & $2.25(.96)$ & .098 & -.19 & $\begin{array}{c}\text { Somewhat } \\
\text { likely }\end{array}$ \\
$\begin{array}{l}\text { Mediate/Problem solve with } \\
\text { cyber bully and victim }\end{array}$ & $1.81(1.08)$ & .068 & .24 & $\begin{array}{c}\text { Somewhat } \\
\text { unlikely }\end{array}$ \\
$\begin{array}{l}\text { Report incident to cyber bully's } \\
\text { parents }\end{array}$ & $2.03(1.02)$ & .875 & .02 & \\
$\begin{array}{l}\text { Report incident to victim's } \\
\text { parents }\end{array}$ & $2.01(1.04)$ & .780 & .04 & \\
$\begin{array}{l}\text { Report incident to school } \\
\text { administrators }\end{array}$ & $2.34(1.05)$ & .849 & -.02 & \\
\hline
\end{tabular}

Note. Response options: $0=$ Very Unlikely; 1=Unlikely; 2=Undecided; $3=$ Likely; $4=$ Very Likely

${ }^{a} p$ values are based on comparisons made between the overall mean for this group of questions $(M=2.0502)$ and the mean for the specific responses to each question.

${ }^{\mathrm{b}}$ Absolute Value of Cohen's $d \geq .2=$ Small; $\geq .5=$ Medium; $\geq .8=$ Large 
Table 6

Teachers' Likelihood to Respond to Cyber Bullying at School Versus Away From School

\begin{tabular}{|c|c|c|c|}
\hline \multirow{2}{*}{$\begin{array}{l}\text { When aware of students' cyber } \\
\text { bullying ... how likely are } \\
\text { you to take the following } \\
\text { actions? }\end{array}$} & \multicolumn{2}{|c|}{ Mean $(S D)$} & \multirow{2}{*}{$\begin{array}{c}\text { Statistical Significance } \\
\qquad p(2 \text {-tailed })\end{array}$} \\
\hline & At school & Away from school & \\
\hline Do nothing & 1.60 & $1.84(1.12)$ & .092 \\
\hline Talk with the cyber bully & $2.72(.84)$ & $2.06(.99)$ & .000 \\
\hline Talk with the victim & $2.81(.78)$ & $2.25(.99)$ & .000 \\
\hline $\begin{array}{l}\text { Take away cyber bully's } \\
\text { privileges }\end{array}$ & $2.69(.95)$ & $1.80(1.09)$ & .000 \\
\hline $\begin{array}{l}\text { Mediate/Problem solve with } \\
\text { cyber bully and victim }\end{array}$ & $2.62(.78)$ & $2.03(1.03)$ & .000 \\
\hline $\begin{array}{l}\text { Report incident to cyber } \\
\text { bully's parents }\end{array}$ & $2.46(.84)$ & $2.01(1.05)$ & .000 \\
\hline $\begin{array}{l}\text { Report incident to victim's } \\
\text { parents }\end{array}$ & $2.42(.85)$ & $2.07(1.05)$ & .000 \\
\hline $\begin{array}{l}\text { Report incident to school } \\
\text { administrators }\end{array}$ & $2.99(.84)$ & $2.34(1.17)$ & .000 \\
\hline
\end{tabular}

Note. $N=66$. Response options: $0=$ Very Unlikely; 1=Unlikely; 2=Undecided; 3=Likely; 4= Very Likely 
Table 7

Average Cohen's d Effect Size of Teachers' Perceptions of Bully Prevention Strategies

\begin{tabular}{|c|c|c|c|}
\hline $\begin{array}{l}\text { How helpful would these bully prevention } \\
\text { strategies be in reducing cyber bullying at your } \\
\text { school? }\end{array}$ & $M(S D)$ & Cohen's $d$ & Interpretation \\
\hline Increased supervision in certain areas & $1.91(1.30)$ & .14 & \\
\hline More specific school policies & $1.97(1.17)$ & .10 & \\
\hline School-wide anti-bully assemblies & $1.72(1.19)$ & .32 & $\begin{array}{c}\text { Somewhat less } \\
\text { helpful }\end{array}$ \\
\hline $\begin{array}{l}\text { Facilitate school climate encouraging students } \\
\text { to report cyber bullying }\end{array}$ & $2.13(1.22)$ & -.02 & \\
\hline $\begin{array}{l}\text { Establish a school bullying task force to develop } \\
\text { anti-bullying policies }\end{array}$ & $1.82(1.22)$ & .22 & $\begin{array}{c}\text { Somewhat less } \\
\text { helpful }\end{array}$ \\
\hline $\begin{array}{l}\text { Encourage bystanders to stand up against cyber } \\
\text { bullies }\end{array}$ & $2.19(1.16)$ & -.08 & \\
\hline Classroom anti-bully lessons & $1.71(1.19)$ & .29 & $\begin{array}{l}\text { Somewhat less } \\
\text { helpful }\end{array}$ \\
\hline Professional development teacher seminars & $1.71(1.09)$ & .30 & $\begin{array}{c}\text { Somewhat less } \\
\text { helpful }\end{array}$ \\
\hline Increased consequences for cyber bullying & $2.52(1.15)$ & -.38 & $\begin{array}{c}\text { Somewhat more } \\
\text { helpful }\end{array}$ \\
\hline Warn about consequences for cyber bullying & $2.35(1.22)$ & -.23 & $\begin{array}{c}\text { Somewhat more } \\
\text { helpful }\end{array}$ \\
\hline Increased parental involvement & $2.79(1.18)$ & -.59 & More helpful \\
\hline
\end{tabular}

* Absolute Value of Cohen's $d \geq .2=$ Small; $\geq .5=$ Medium; $\geq .8=$ Large Note. Response options: $0=$ Not helpful; $1=$ Slightly helpful; $2=$ Somewhat helpful; $3=$ Helpful; $4=$ Very helpful. 
Table 8

Teachers' Ideas About What Works to Decrease Cyber Bullying

\begin{tabular}{|c|c|c|}
\hline General Idea & $\begin{array}{l}\text { Percent of } \\
\text { Responses }\end{array}$ & Sample Responses \\
\hline Educate students & $30 \%$ & $\begin{array}{l}\text { - "Teaching the consequences seen in the news. Role } \\
\text { playing bullying and discussion of real life } \\
\text { consequences." } \\
\text { - "Teaching kids to stand up to cyber bullies." } \\
\text { - "Teaching the opposite and good behaviors and then } \\
\text { expecting it, while having consequences and learning } \\
\text { opportunities prepared for when it [bullying] happens." }\end{array}$ \\
\hline $\begin{array}{l}\text { Limit access to } \\
\text { electronics }\end{array}$ & $22 \%$ & $\begin{array}{l}\text { - "Don't give teens unfettered access to electronic } \\
\text { devices." } \\
\text { - "Continue to not allow electronic devices in the } \\
\text { classroom." }\end{array}$ \\
\hline $\begin{array}{l}\text { Educate parents / } \\
\text { parental support }\end{array}$ & $7.5 \%$ & $\begin{array}{l}\text { - "Education and good communication between students, } \\
\text { teachers and parents." } \\
\text { - "This is a tough one. Parents need to be taught how to } \\
\text { deal with this and help." } \\
\text { - "Educating parents (and maybe students) on cyber } \\
\text { bullying and its legal or school-related consequences." }\end{array}$ \\
\hline
\end{tabular}

Note. Of the 66 participating teachers, 39 provided comments. These percentages are based on the 39 who provided comments. 


\section{APPENDIX A}

\section{Literature Review}

Holly Grogan was said by her family to be "a wonderful daughter and sister" (Bird, 2009). Her friend described her as having the biggest smile in the world. Tragically, on September 16, 2009, Holly was pronounced dead, a victim of cyber bullying. Holly ended her life by jumping from a 30-foot bridge near Gloucester (UK). Schoolmates had reportedly posted a string of mean-spirited messages on her Internet Facebook page. To distance herself from hateful comments, Holly moved and switched schools, hoping for a fresh start. However, moving did not stop the bullying. A close friend of Holly's told reporters that girls from the old school spread rumors to the new school and the tormenting continued.

Holly Grogan's name joins the growing list of victims who completed suicide to escape relentless cyber bullying. Holly Grogan, Megan Meier, Ryan Halligan, and others have been spotlighted in the media for their tragic experiences involving cyber bullying. However, cyber bullying affects more than the few cases reported in the news. In the following sections, important studies on cyber bullying were reviewed and information presented regarding (a) significant features of cyber bullying, including prevalence rates and the short and long term impact of cyber bullying; (b) difficulties administrators face in dealing with cyber bullying; and (c) research-based recommendations to implement more effective anti-cyber bullying programs.

\section{Cyber Bullying}

Considered the father of bullying research, Dan Olweus (1993) explained that bullying occurs when a student is exposed, repeatedly and over time, to negative actions on the part of one or more students. After investigating definitions of bullying in academic literature, Greene (2000) provided five key features of bullying, including: (a) the bully intends to inflict harm or 
fear upon the victim, (b) the aggression occurs repeatedly, (c) the victim does not provoke the behavior of the bully, (d) the bully perpetrates in familiar social groups, and (e) the bully is perceived as more powerful (either socially or physically) than the victim.

Vandebosch and Van Cleemput (2007) pointed out four difficulties in simply transforming the definition of bullying to accommodate the realm of cyber bullying. First, the communication (such as an e-mail or text message) may not be malicious in nature, but may be perceived as harmful due to the lack of nonverbal expressive cues, such as tone of voice and facial expressions. Second, because repetition is a necessary ingredient in traditional bullying, it is unclear if one act of cyber bullying officially constitutes bullying. However, due to the nature of the Internet, isolated remarks posted on one occasion may be distributed, passed along within and across various networks of friends, and may remain on websites indefinitely. Third, cyber bullying clearly occurs both within and outside of familiar groups. In fact, many victims are unaware of the cyber bully's identity. Fourth, with easy access to technology and minimal knowledge required to perpetrate cyber bullying, the imbalance of power, an ingredient in traditional bullying, may not apply in this new realm of bullying.

Cognizant of these differences, Willard (2007b) abandons several required elements of traditional bullying. Very simply, she defines cyber bullying as, "sending or posting harmful or cruel text or images using the Internet or other digital communication devices” (2007b, p. 2).

Types of cyber bullying. Cyber bullying is perpetrated through a variety of methods and technologies. A common list of cyber bullying outlets includes instant messaging, e-mailing, text messaging, participating on social networking sites such as MySpace or Facebook, and taking part in chat rooms, blogs, web sites, bash boards, and internet gaming (Kowalski et al., 2008). 
Cyber bullying can also be perpetrated through video sites such as YouTube, picture and video messaging, and phone calls.

Based on research conducted by Smith et al. (2008), students reported phone calls and text messaging as the most common forms of cyber bullying, both inside and outside of school. However, students were most aware of cyber bullying with video clips and photos. Research by Raskauskas and Stoltz (2007) indicated that 32\% of respondents reported being cyber bullied through text messaging, followed by $15.5 \%$ who reported being cyber bullied on an internet website.

Kowalski and Limber (2007) reported instant messaging as the primary medium of cyber bullies, with $66.6 \%$ of respondents reporting being victimized by this type of cyber bullying. The next most common forms of cyber bullying occurred through chat rooms, e-mail, and websites $(24.7 \%, 24.2 \%$, and $23.4 \%$ respectively).

Prevalence rates of cyber bullying. Although the prevalence rates for traditional bullying have been established, research on cyber bullying is more recent. However, over the past few years researchers have begun to describe this previously unexplored area of bullying.

In a recent study of UK students, about $3.1 \%$ of participants ages 11 to 16 reported being victims of cyber bullying "over a year ago," compared to $10.4 \%$ in the current school term (Smith et al., 2008). Smith et al. also reported that $6.6 \%$ of the adolescents indicated having been cyber bullied "often" over the past couple of months, while another $15.6 \%$ responded that they had been cyber bullied "once or twice" in the same time period.

Based on several studies conducted in Canada, Li $(2006,2007)$ revealed that between 14$16 \%$ of participants in grades $7-9$ had participated in cyber bullying. Almost $25 \%$ of participants 
reported being victimized by cyber bullying, $40 \%$ of whom had experienced cyber bullying four or more times.

A study of middle school students in both the southeastern and northwestern United States, found that nearly $18 \%$ of those involved in the study had been victims of cyber bullying within the previous two to three months (Kowalski \& Limber, 2007). Within that same time frame, close to $11 \%$ of participants had perpetrated cyber bullying.

Most studies regarding the prevalence of cyber bullying in schools admit that their findings most likely underestimate the problem. This is due to the fact that many questionnaires offer an operational definition of "cyber bullying." This definition may not be fully understood by participants and/or the definition may not be accurately remembered when students answer questions. For instance, when asked, "Have you been a victim of cyber bullying within the last 2 to 3 months?" some students may not consider certain behaviors as acts of cyber bullying even though these behaviors may fall under the prescribed definition. Even considering the underestimation of cyber bullying and the fact that prevalence rates vary across studies, the consensus and most important finding across studies is that cyber bullying is a problem, and it is increasing (Kowalski et al., 2008).

Age differences in cyber bullying. Few studies examine the relationship between age and involvement in cyber bullying. Several key studies do however, provide preliminary information regarding the ages of those involved in cyber bullying. Looking at instances of cyber bullying among students in Sweden, Slonje and Smith (2008) found that cyber bullying was much more common among students ages 12 to 15 than among older students ages 15 to 20 .

Other studies have shown greater involvement in cyber bullying among older students. In a nationwide study of nearly 1,500 youth, ages 10 to 17, Ybarra and Mitchell (2004b) found that 
involvement in online harassment of others increased from $1.1 \%$ of 10 to 12 -year-olds; to $4.1 \%$ of 13 to 14 -year-olds; to $9.7 \%$ of 15 to 17 -year-olds. In another study comparing age differences, in comparison to 6 th grade students, students in 7 th and 8 th grade were twice as likely to have been involved in cyber bullying, either as perpetrators or bully/victims (Kowalski \& Limber, 2007).

Gender differences in cyber bullying. In a study conducted by $\mathrm{Li}$ (2006), 22\% of males and $12 \%$ of females reported perpetrating cyber bullying. Although males were almost twice as likely to perpetrate cyber bullying, equal numbers of males and females $(25 \%$ of males and $25.6 \%$ of females) reported being victims of cyber bullying. Li also noted that female students were more likely than males to report cyber bullying to an adult.

Kowalski and Limber (2007) reported that among middle school students, $15 \%$ of females and $7 \%$ of males indicated they were victimized by cyber bullying. About $10 \%$ of females reported having been involved as both perpetrator and victim of cyber bullying, while only $4 \%$ of males reported this dual role. Finally, $4 \%$ of females reported acting in the sole role of cyber bully, compared to $5 \%$ of males.

Slonje and Smith (2008) found that boys were only slightly more likely than girls to report being a cyber bully. However, when victims were asked the gender of their cyber bully, $36 \%$ responded that they were bullied by a boy, while only $12 \%$ responded being bullied by a girl. Interestingly, about $36 \%$ of victims reported not knowing the gender of their perpetrator, showcasing the anonymity that often accompanies cyber bullying. In comparison to boys, girls were also more likely to be victims of e-mail cyber bullying.

Smith et al. (2008) found somewhat different results, with $40 \%$ of cyber bullies described as one or more girls, $31 \%$ described as one or more boys; and $25.7 \%$ described as unknown 
gender. Though student participants in this study generally thought that girls would be more involved in cyber bullying than boys, data indicated that girls were only more likely to be victims of cyber bullying.

Though the rates of male and female involvement in cyber bullying vary across research studies, it seems clear that we can no longer accept the simple view that boys use physical bullying while girls use relational and less overt forms of bullying. Cyber bullying is often described as indirect and relational in nature, but in comparison to girls, boys appear to be equally involved, or even more involved in this type of bullying.

Effects of cyber bullying. Despite recent and highly publicized incidents involving cyber bullying and resulting suicides, few studies focus on the specific effects of cyber bullying as opposed to traditional bullying. In a study conducted by Raskauskas and Stoltz (2007), 93\% of victims of cyber bullying reported feeling that cyber bullying had negatively affected them. When asked in what ways cyber bullying had affected them, the most common responses were, "it made me feel sad, hopeless or depressed" ( $n=58 \%)$, and "made me afraid to go to school" $(n=29 \%)$. When victims were uncertain of who had bullied them, nearly half responded that this uncertainty made them suspicious of others.

Hinduja and Patchin (2007) also reported that of those who had been victims of cyber bullying, 30\% responded that they felt "angry" and 34\% felt "frustrated" as a result of the cyber bullying. Kowalski et al. (2008) listed over 20 recorded instances of cyber bullying with victims describing various emotional responses ranging from depression and anxiety, physical symptoms such as stomach ulcers, and thoughts and behaviors related to suicide.

Ybarra and Mitchell (2004b) indicated that one-third of cyber bullying victims reported feeling "emotionally distressed" as a result of online harassment. Perhaps a more interesting 
finding is that, in comparison to victim-only peers, students who were both victims and aggressors of cyber bullying were six times as likely to report emotional distress. Of those who were termed bully/victims, $44 \%$ reported behavior problems. About one quarter of bully/victims reported having engaged in drinking multiple times; $23 \%$ reporting having smoked on multiple occasions. They also reported the highest rates of depressive symptoms (16\%) compared to any other group of students (bullies, victims, and those not involved with cyber bullying). The effects of cyber bullying appear to negatively impact not only victims, but those who perpetrate cyber bullying.

\section{Relationship Between Cyber Bullying and Traditional Bullying}

In a study of Swedish students ages 12 to 20-years-old, Slonje and Smith (2008) found that of the $9 \%$ of participants who had been victimized by traditional bullying, only $1 \%$ of those students reported cyber bullying others within the previous 2 to 3 months. Raskauskas and Stoltz (2007) also reported no statistically significant evidence to indicate that students who were victims of traditional bullying were any more likely to cyber bully than students who were not victimized.

Li (2007), however, in examining 7th graders in Canada, found much stronger correlations between traditional and cyber bullying. Nearly $30 \%$ of participants who reported having bullied also reported having cyber bullied. Similarly, Li found that almost $33 \%$ of victims of traditional bullying were also victims of cyber bullying. In contrast to other studies, about $16 \%$ of those victimized by traditional bullying cyber bullied others. However, when interpreting these findings it is important to consider that the survey questions simply asked if students had ever been involved in these activities (no specified time frame). 
Also finding a connection between bullying and cyber bullying, Ybarra and Mitchell (2004b) found that over half of those who participated in cyber bullying also reported being victims of traditional bullying during the previous year. Supporting these findings, research conducted by Vandebosch and Van Cleemput (2007) indicated that traditional bullies were typically involved in cyber bullying, and victims of traditional bullying were also typically victims of cyber bullying.

\section{Special Issues with Cyber Bullying}

Cyber bullying presents some special challenges when compared with other forms of bullying. Cyber bullying occurs in many settings where traditional bullying never ventured. Students can become victims to cyber bullying while sitting at a computer at home. They may be unaware that someone targeted them and was using the internet against them until they stumbled upon the website weeks or months later (Kowalski et al., 2008).

Slonje and Smith (2008) found that being a victim of cyber bullying occurred more often outside of school than inside school, with significantly more text message victimization and phone call victimization occurring outside of school. Smith et al. also found that cyber bullying occurred more frequently outside of school (11.1\%) as opposed to inside of school (3.4\%).

Another issue surrounding cyber bullying is that the victim often does not want to tell an adult for fear of receiving less time on the internet or having their cell phone taken away (Kowalski et al., 2008). According to Slonje and Smith (2008), 50\% of cyber bullying victims reported not telling anyone, while $35.7 \%$ told a friend, $8.9 \%$ told a parent or guardian, and $5.4 \%$ told someone else. Interestingly, of the 210 respondents indicating they had been victims of traditional or cyber bullying, not one reported telling a teacher. Consistent with other studies, 
Smith et al. (2008) found that nearly $44 \%$ of cyber bullying victims told no one; however their study indicated that $17 \%$ of youth reported telling a teacher or other adult at school.

Victims of cyber bullying are also typically unsure of the bully's identity. Li (2007), found that $40.9 \%$ of seventh grade victims did not know who had cyber-bullied them. Other studies among students in Belgium (Vandebosch \& Van Cleemput, 2007) and the United States (Kowalski \& Limber, 2007) reported similar findings with elementary and middle school students - nearly half of all victims of cyber bullying were unable to identify the perpetrator.

\section{Legal Issues and Cyber Bullying}

As cyber bullying is a relatively new phenomenon, there is little case law to guide decision-making by educational administrators (Willard, 2007a). Willard addresses the issues of "authority" and "responsibility" of schools in dealing with cyber bullying issues. Authority is the legally justified right to impose formal discipline, while responsibility is the legal obligation to protect students. In the case of Tinker v. Des Moines (1969), it was acknowledged that school officials were permitted to prohibit student speech if the speech "would substantially interfere with the work of the school or impinge upon the rights of other students" (p. S64). School districts, however, must be able to show that the action was warranted. Willard recommends that districts carefully document the evidence leading up to a disciplinary decision.

As to the issue of responsibility, Willard (2007a) argues that if a school official has knowledge of "online harmful speech," that creates or has created a hostile educational environment, impairing students' ability to receive an education, that official must take "corrective action" (2007a). Willard recommends that districts consult with their attorneys regarding specific instances of cyber bullying, but states that schools have the authority and 
responsibility to take action against cyber bullying, and could be held legally responsible for not taking action.

Kowalski et al. (2008) point out the importance of the language used by Willard. The school must be able to show that the speech of a student has "substantially" interfered with the school work of the affected student. Schools should be aware that "flame" comments (criticisms of schools, school administrators, teachers, etc.) posted on websites should be examined carefully before action is taken, as automatic suspension or other actions could be viewed as free speech violations, and have resulted in a host of recent law suits against school districts (Kennedy, 2006). If such comments are posted through school computers, the student is subject to school and district policy. The issue arises when the offending comments are posted through a computer at home or any other computer not at school.

While schools will likely still face difficulties trying to suppress cyber bullying that occurs outside of school, administrators seem to face a legal obligation to deal with cyber bullying on school grounds especially: (a) If the speech constitutes a threat; (b) if the speech is lewd, vulgar, or profane; (c) when the speech is (or appears to be) sponsored by the school; or (d) when the speech materially disrupts the school or the rights of others (Kowalski et al., 2008). For a more comprehensive discussion of applications of supreme court and other legal determinations applied to potential cyber bullying incidents and schools, see Zande (2009).

\section{Recommended Strategies to Deter Cyber Bullying}

Despite the unique problems presented by cyber bullying, researchers suggest many of the same preventative measures as with traditional bullying. Li (2006) presents several suggestions for working with cyber bullying in schools. Education of the large majority of bystanders has great potential in preventing cyber bullying. Students should know and 
understand effective strategies (such as informing adults) for dealing with cyber bullies. Li also suggests that education of dealing with cyber bullying should not be limited to schools only, but needs to be a joint endeavor of schools, families, and communities.

Bhat (2008) emphasizes the need for school personnel, including teachers, support staff, and administration, to familiarize themselves with the current technologies used in cyber bullying. MySpace.com, for example, has an online guide specifically for school personnel to help inform about what social networking sites are and how they work. The guide also provides concrete steps that school administration should follow if alerted to cyber bullying taking place through MySpace.com. School employees should be prepared and know what to do in the case of being alerted to cyber bullying, which will only happen by becoming informed.

Incorporation of cyber bully scenarios in classroom discussion is also advised as a helpful way of addressing the issue directly with students (Bhat, 2008). Students should also be aware that cyber bullying can be traced even though they don't use their own name online, and that they could face criminal charges for involvement in cyber bullying.

Parents can also get involved by monitoring their children's usage of the internet and mobile phones, and having "clear internet and mobile phone agreements" with their children (The Alannah and Madeline Foundation, 2007). Parents should help children understand what is considered acceptable communication online and over cell phones, and what is not (Beale \& Hall, 2007; Bhat, 2008; Kowalski \& Limber, 2007).

Ybarra and Mitchell (2004b) noted that youth reporting low parental closeness were nearly 3 times more likely to participate in cyber bullying than those reporting average or better closeness with parents. Similarly, they found that youth reporting low parental monitoring were 
over twice as likely to engage in cyber bullying (see also Vandebosch \& Van Cleemput, 2007). Prevention programs would do well to address this interaction.

Beale and Hall (2007) recommend assessing the level of cyber bullying occurring both at home and in the schools. They also recommend that gaps in perception and knowledge of cyber bullying be assessed by using focus groups, class meetings, and surveys sent to teachers, parents, and students. It is important that teachers, staff, parents, and students understand the seriousness of cyber bullying and its potential legal implications. Further recommendations include: collaborating with local police departments to invite "cybercops" to speak with students and parents about proper internet use, creating a school environment where students feel comfortable talking with teachers or other adults about issues, including cyber bullying, and integrating internet bully lessons into the school curriculum.

Olweus' well-recognized program for traditional bullying intervention may also provide a good framework for interventions with cyber bullying. This program is based on four key principles: (1) warmth, positive interest, and involvement from adults; (2) firm limits on unacceptable behavior; (3) consistent application of non-punitive, nonphysical sanctions for unacceptable behavior or violations of rules; and (4) adults who act as authorities and positive role models (Olweus, 2003).

\section{Perceptions of Cyber Bullying}

It has been mentioned that time and money may be wasted when prevention programs are implemented without giving importance to perceptions of those involved - particularly teachers. Awareness of student and teacher perceptions will help guide more effective intervention and prevention programs. 
Students' perceptions of cyber bullying. In response to questions of how damaging cyber bullying can be, Slonje and Smith (2008) found mixed results. One student remarked, "This kind of bullying is quite inoffensive compared to traditional bullying. Concentrate on getting rid of that," while another stated, "I believe that cyberbullying hurts the person more psychologically, I don't mean that ordinary bullying does not do it but I think that the effect becomes more psychological. You become more frightened if you e.g. get a sms [text message] that says: 'I will kill you.'” Students generally agreed that adults are less aware of text, e-mail, and phone call bullying than of traditional bullying.

When asked to report the impact of cyber bullying on the victim in comparison to traditional bullying, students generally reported that the effects were the same or slightly less, with the consistent exception of video clip and picture cyber bullying, which was seen as significantly more damaging (Slonje \& Smith, 2008; Smith et al., 2008).

Middle school and high school students $(n=148)$ involved in focus groups conducted by Agatston, Kowalski and Limber (2007) generally remarked that cyber bullying was a problem at their schools, though male students were less likely to agree with their female peers.

When asked if adults in school try to stop cyber bullying when informed of it, about $33 \%$ of seventh grade participants responded that they did not (Li, 2007). Agatston et al. (2007) reported that most students involved in focus groups indicated that they did not believe that adults at school could help if they were having problems with cyber bullying. Most students mentioned that they didn't believe teachers would intervene because the cyber bullying generally takes place at home, not at school (Kowalski et al., 2008).

Teachers' perceptions of cyber bullying. In a study of teachers' perceptions and practices regarding traditional bullying prevention and intervention, Drake, Price, Telljohann, 
and Funk (2003) found that the only bullying-related activity in which most teachers participated $(86.3 \%)$ was talking with both the bully and the victim after a situation arose. While this intervention can be helpful, it takes the "putting out the fire" approach rather than a preventative stance that has been shown to be more effective (Olweus, 2003). Effective prevention strategies such as setting aside class time to discuss bullying and involving students in classroom rule making that addresses bullying were used by less than one-third of teachers. Over $80 \%$ of the teachers involved in the study mentioned that bullying was an issue in their classroom, but rated the previously mentioned preventative strategies as "moderately effective." Researchers propose that while teachers may have been introduced to effective prevention techniques, they may not be aware of their effectiveness, or may feel inadequate to implement such preventative measures without the support of the school. Drake et al. (2003) emphasize the need for further research that examines perceptions of the effectiveness of proven bullying prevention strategies so that programs can be implemented with sensitivity to current beliefs.

Olweus (2003) notes that, "The attitudes and routines of relevant adults can exacerbate or curb students' aggression towards classmates” (p. 12). If relevant adults such as teachers, administrators, and other school officials maintain a vague idea of what constitutes "cyber bullying," little progress is likely to be made in curbing its use. However, Olweus would probably suggest that when adults perceive cyber bullying as something to be taken seriously, with significant effects for those that experience it, changing vague definitions for firm understanding, the effects are likely to be felt school-wide. 


\section{Appendix B \\ Teacher Questionnaire}

Dear Participant,

Background information: We are requesting your participation in completing a survey on the topic of bullying and cyber bullying. As requested by the State Board of Education, and as mandated by the Utah State Legislature, all Utah School Districts are required to draft and implement bullying and cyber bullying policies. Additionally during the 2009-2010 school-year, districts must have a bully prevention program in place. In response to this need, [the] School District, with the assistance of Melissa Allen Heath, Brigham Young University's Associate Professor in the Department of Counseling Psychology and Special Education, are gathering information to inform planning and monitor bullying and cyber bullying prevention and intervention efforts. Your input is critical in gathering accurate information and understanding this important topic. [The] District considers bullying a high priority topic and is eager to meet the needs of their teachers and students.

Description of survey: The survey consists of 13 short sections of questions asking the participant to select from a short selection of potential response options; 5 brief open-ended questions; and 6 demographic questions. The five open-ended questions require short typed responses (text boxes are provided).

Time required to complete survey: The survey takes approximately 20 minutes to complete. By participating in this survey, you indicate your informed consent and permission to have this survey data entered into the individual school's and also the district's data set. Your responses are not linked to personally identifying information. Surveys are anonymous. Additionally, anonymity is maintained throughout the survey and a participant's identity is not linked to specific responses.

Consent to participate: This survey is not expected to cause harm or undue distress; however, you may find this survey thought provoking, possibly eliciting memories associated with bullying. Respecting your rights as a participant in this study, you have the right to discontinue participation and withdraw at any point. However, we encourage your participation because [the] School District greatly values your perceptions and input. If you chose to participate, click the internet link pasted below, and follow the directions for completing the online survey. Completion of this survey indicates your voluntary consent to participate in this study.

Questions or concerns? Contact information: This survey was reviewed and approved by [the] School District (under the direction of [the] Director of Special Services) and the McKay School of Education subcommittee of Brigham Young University's Institutional Review Board (IRB). If you have questions or concerns, please contact the primary investigator, Melissa Allen Heath (contact information is listed below). You may also contact the Brigham Young University Institutional Review Board (IRB) office: Please email the ORCA Office: orcastu@byu.edu or call the IRB staff: 801-422-3841. If you have questions regarding your rights as a research participant, please contact Dr. Chris Dromey at (801) 422-6461, at christopherdromey@byu.edu, or at 133 TLRB, Brigham Young University, Provo, UT 84602. 
Thank you for your participation!

Bullying: Includes intentionally inflicting harm or discomfort upon another person more than once through: physical aggression such as hitting or pushing, verbal harassment such as name calling or verbal threats, or relational aggression such as gossiping or isolating or excluding an individual from a social group.

Cyber Bullying: Includes sending offensive, rude, or insulting messages, videos, or pictures through: text messaging, e-mail, instant messaging, blogs, social networking websites, or other electronic mediums.

In the past three months, how often has the following occurred with your students? Never Rarely Monthly Weekly Daily Once per

\begin{tabular}{|c|c|c|c|c|c|}
\hline Bullying (check one) & $C$ & $C$ & $C$ & $C$ & $C$ \\
\hline $\begin{array}{l}\text { Cyber bullying } \\
\text { (check one) }\end{array}$ & {[} & C & C & $\mathrm{C}$ & $\mathbb{C}$ \\
\hline
\end{tabular}

To what extent are these behaviors a problem in your school?

$\begin{array}{llllll} & \text { No Problem } & \text { Minor } & \text { Moderate } & \text { Considerable } & \text { Serious } \\ \text { Bullying } & & \text { Problem } & \text { Problem } & \text { Problem } & \text { Problem } \\ \text { Cyber bullying } & \mathbf{C} & \mathbf{C} & \mathbf{C} & \mathbf{C} & \mathbf{C} \\ & \mathbb{C} & \mathbf{C} & \mathbf{C} & \mathbf{C} & \mathbf{C}\end{array}$

To what extent do you agree with the following statements?

$\begin{array}{llllll} & \text { Strongly } & \text { Disagree } & \text { Neutral } & \text { Agree } & \text { Strongly } \\ \text { Bullying toughens kids up } & \text { Disagree } & \mathbf{C} & \mathbf{C} & \mathbf{C} & \mathbf{C} \\ \text { Bullying has long lasting negative effects } & \mathbf{C} & \mathbf{C} & \mathbf{C} & \mathbf{C} & \mathbf{C} \\ \text { Bullying prepares students for life } & \mathbf{C} & \mathbf{C} & \mathbf{C} & \mathbf{C} & \mathbf{C} \\ \text { Cyber bullying toughens kids up } & \mathbf{C} & \mathbf{C} & \mathbf{C} & \mathbf{C} \\ \begin{array}{l}\text { Cyber bullying has long lasting negative } \\ \text { effects }\end{array} & \mathbf{C} & \mathbf{C} & \mathbf{C} & \mathbf{C} & \mathbf{C} \\ \text { Cyber bullying prepares students for life } & \mathbf{C} & \mathbf{C} & \mathbf{C} & \mathbf{C} & \mathbf{C}\end{array}$

During your class, what percent of students use electronic devices? (Rate each item 0 - 100, do not include a \% symbol)

Cell phone

Classroom computer

Personal computer

Percent 
How often does bullying occur in the following locations?

\begin{tabular}{lllllll} 
& Never & \multicolumn{2}{l}{ Infrequently Sometimes Often } & \multicolumn{2}{c}{ Always } & $\begin{array}{l}\text { Don't } \\
\text { Know }\end{array}$ \\
Inside school building & $\mathbf{C}$ & $\mathbf{C}$ & $\mathbf{C}$ & $\mathbf{C}$ & $\mathbf{C}$ & $\mathbf{C}$ \\
$\begin{array}{l}\text { Outside school building but on } \\
\text { school grounds }\end{array}$ & $\mathbf{C}$ & $\mathbf{C}$ & $\mathbf{C}$ & $\mathbf{C}$ & $\mathbf{C}$ & $\mathbf{C}$ \\
$\begin{array}{l}\text { Away from school and school } \\
\text { grounds }\end{array}$ & $\mathbf{C}$ & $\mathbf{C}$ & $\mathbf{C}$ & $\mathbf{C}$ & $\mathbf{C}$ & $\mathbf{C}$
\end{tabular}

How often does cyber bullying occur in the following locations?

\begin{tabular}{lllllll} 
& Never & \multicolumn{2}{l}{ Infrequently } & Sometimes Often & \multicolumn{2}{c}{ Always } \\
Inside school building & $\mathbf{C}$ & $\mathbf{C}$ & $\mathbf{C}$ & $\mathbf{C}$ & $\mathbf{C}$ & $\mathbf{C}$ \\
$\begin{array}{l}\text { Outside school building but on } \\
\text { school grounds }\end{array}$ & $\mathbf{C}$ & $\mathbf{C}$ & $\mathbf{C}$ & $\mathbf{C}$ & $\mathbf{C}$ & $\mathbf{C}$ \\
$\begin{array}{l}\text { Away from school and school } \\
\text { grounds }\end{array}$ & $\mathbf{C}$ & $\mathbf{C}$ & $\mathbf{C}$ & $\mathbf{C}$ & $\mathbf{C}$ & $\mathbf{C}$
\end{tabular}

Should a formal bully prevention program be implemented in your school?

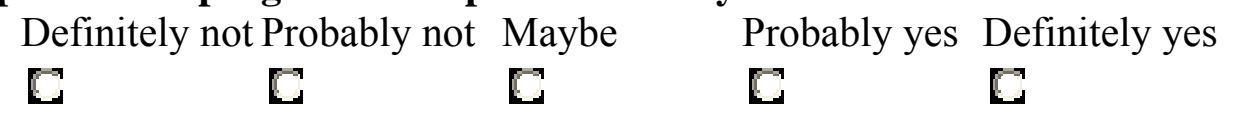

How helpful would these bully prevention strategies be in reducing bullying at your school?

\begin{tabular}{|c|c|c|c|c|c|}
\hline & Not helpful & $\begin{array}{l}\text { Slightly } \\
\text { helpful }\end{array}$ & $\begin{array}{l}\text { Somewhat } \\
\text { helpful }\end{array}$ & Helpful & Very helpful \\
\hline $\begin{array}{l}\text { Increased supervision in } \\
\text { certain areas }\end{array}$ & $\mathbb{C}$ & $\mathbf{E}$ & $\mathrm{C}$ & $\mathbf{C}$ & $\mathbf{E}$ \\
\hline $\begin{array}{l}\text { More specific school } \\
\text { policies }\end{array}$ & $\mathbf{C}$ & $\mathbf{C}$ & $\mathbf{C}$ & C & $\mathbf{E}$ \\
\hline $\begin{array}{l}\text { School-wide anti-bully } \\
\text { assemblies }\end{array}$ & $\mathrm{C}$ & $\mathbf{C}$ & $\mathrm{C}$ & $\mathbf{C}$ & $\mathrm{C}$ \\
\hline \multirow[t]{2}{*}{$\begin{array}{l}\text { Facilitate school climate } \\
\text { encouraging students to } \\
\text { report bullying }\end{array}$} & C & $\mathbf{C}$ & $\mathbf{C}$ & 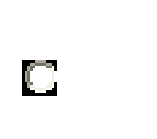 & C \\
\hline & Not helpful & $\begin{array}{l}\text { Slightly } \\
\text { helpful }\end{array}$ & $\begin{array}{l}\text { Somewhat } \\
\text { helpful }\end{array}$ & Helpful & Very helpful \\
\hline $\begin{array}{l}\text { Establish a school bullying } \\
\text { task force to develop anti- } \\
\text { bullying policies }\end{array}$ & $\mathbf{C}$ & $\mathbf{C}$ & 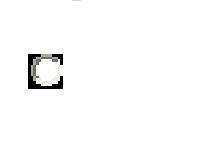 & $\mathbb{C}$ & $\mathbf{C}$ \\
\hline $\begin{array}{l}\text { Encourage bystanders to } \\
\text { stand up against bullies }\end{array}$ & $\mathbb{C}$ & $\mathbb{C}$ & $\mathrm{C}$ & $\mathbb{C}$ & $\mathbf{C}$ \\
\hline $\begin{array}{l}\text { Classroom anti-bully } \\
\text { lessons }\end{array}$ & C & $\mathbb{C}$ & $\mathbf{C}$ & C & $\mathbb{E}$ \\
\hline $\begin{array}{l}\text { Professional development } \\
\text { teacher seminars }\end{array}$ & $\mathbb{C}$ & $\mathbf{C}$ & $\mathbf{C}$ & $\mathbf{E}$ & $\mathbf{E}$ \\
\hline
\end{tabular}


How helpful would these bully prevention strategies be in reducing bullying at your school?

$\begin{array}{llllll} & \text { Not helpful } & \begin{array}{l}\text { Slightly } \\ \text { helpful } \\ \text { Slightly } \\ \text { helpful }\end{array} & \begin{array}{l}\text { Somewhat } \\ \text { helpful } \\ \text { Somewhat } \\ \text { helpful }\end{array} & \text { Helpful } & \text { Very helpful } \\ \begin{array}{l}\text { Increased consequences } \\ \text { for bullying }\end{array} & \mathbf{C} & \mathbf{C} & \mathbf{C} & \mathbf{C} & \text { Very helpful } \\ \begin{array}{l}\text { Warn about consequences } \\ \text { for bullying }\end{array} & \mathbf{C} & \mathbf{C} & \mathbf{C} & \mathbf{C} & \mathbf{C} \\ \begin{array}{l}\text { Increased parental } \\ \text { involvement }\end{array} & \mathbf{C} & \mathbf{C} & \mathbf{C} & \mathbf{C} & \mathbf{C} \\ \begin{array}{l}\text { Other (specify) } \\ \text { (n) }\end{array} & \mathbf{C} & \mathbf{C} & \mathbf{C} & \mathbf{C} & \mathbf{C}\end{array}$

How helpful would these bully prevention strategies be in reducing cyber bullying at your school?

\begin{tabular}{|c|c|c|c|c|c|}
\hline & Not helpful & $\begin{array}{l}\text { Slightly } \\
\text { helpful }\end{array}$ & $\begin{array}{l}\text { Somewhat } \\
\text { helpful }\end{array}$ & Helpful & Very helpful \\
\hline $\begin{array}{l}\text { Increased supervision in } \\
\text { certain areas }\end{array}$ & $\mathbb{C}$ & $\mathrm{C}$ & $\mathbf{C}$ & C & $\mathbf{C}$ \\
\hline $\begin{array}{l}\text { More specific school } \\
\text { policies }\end{array}$ & $\mathbf{C}$ & $\mathrm{C}$ & $\mathbf{C}$ & $\mathbf{C}$ & $\mathrm{C}$ \\
\hline $\begin{array}{l}\text { School-wide anti-bully } \\
\text { assemblies }\end{array}$ & C & $\mathbf{C}$ & $\mathrm{C}$ & C & $\mathbf{C}$ \\
\hline $\begin{array}{l}\text { Facilitate school climate } \\
\text { encouraging students to } \\
\text { report cvber bullving }\end{array}$ & $\mathbb{C}$ & $\mathbf{C}$ & $\mathbf{C}$ & C & $\mathbf{C}$ \\
\hline & Not helpful & $\begin{array}{l}\text { Slightly } \\
\text { helpful }\end{array}$ & $\begin{array}{l}\text { Somewhat } \\
\text { helpful }\end{array}$ & Helpful & Very helpful \\
\hline $\begin{array}{l}\text { Establish a school } \\
\text { bullying task force to } \\
\text { develop anti-bullying } \\
\text { policies }\end{array}$ & C & $\mathbf{C}$ & C & 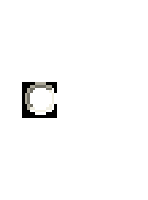 & $\mathrm{C}$ \\
\hline $\begin{array}{l}\text { Encourage bystanders to } \\
\text { stand up against cyber } \\
\text { bullies }\end{array}$ & C & $\mathbf{C}$ & $\mathbf{C}$ & $\mathbb{C}$ & $\mathbf{C}$ \\
\hline $\begin{array}{l}\text { Classroom anti-bully } \\
\text { lessons }\end{array}$ & $\mathbb{C}$ & $\mathbf{C}$ & $\mathbb{C}$ & $\mathbb{C}$ & $\mathrm{C}$ \\
\hline $\begin{array}{l}\text { Professional development } \\
\text { teacher seminars }\end{array}$ & $\mathrm{C}$ & $\mathrm{C}$ & $\mathrm{C}$ & C & $\mathrm{C}$ \\
\hline & Not helpful & $\begin{array}{l}\text { Slightly } \\
\text { helpful }\end{array}$ & $\begin{array}{l}\text { Somewhat } \\
\text { helpful }\end{array}$ & Helpful & Very helpful \\
\hline $\begin{array}{l}\text { Increased consequences } \\
\text { for cyber bullying }\end{array}$ & $\mathbb{C}$ & $\mathrm{C}$ & $\mathbb{C}$ & $\mathbb{C}$ & $\mathbb{C}$ \\
\hline $\begin{array}{l}\text { Warn about consequences } \\
\text { for cyber bullying }\end{array}$ & $\mathbb{C}$ & $\mathbf{C}$ & $\mathbb{C}$ & C & $\mathbf{C}$ \\
\hline
\end{tabular}


How helpful would these bully prevention strategies be in reducing cyber bullying at your school?

\begin{tabular}{llllll} 
& Not helpful & $\begin{array}{l}\text { Slightly } \\
\text { helpful }\end{array}$ & $\begin{array}{l}\text { Somewhat } \\
\text { helpful }\end{array}$ & Helpful & Very helpful \\
$\begin{array}{l}\text { Increased parental } \\
\text { involvement }\end{array}$ & $\mathbf{C}$ & $\mathbf{C}$ & $\mathbf{C}$ & $\mathbf{C}$ & $\mathbf{C}$ \\
Other (specify) & $\mathbf{C}$ & $\mathbf{C}$ & $\mathbf{C}$ & $\mathbf{C}$ & $\mathbf{C}$ \\
\hline
\end{tabular}

When aware of students' bullying at your school, how likely are you to take the following actions?

\begin{tabular}{llllll} 
& Very & Unlikely & Undecided & Likely & Very Likely \\
Do nothing & Unlikely & $\mathbf{C}$ & $\mathbf{C}$ & $\mathbf{C}$ & $\mathbf{C}$ \\
Talk with the bully & $\mathbf{C}$ & $\mathbf{C}$ & $\mathbf{C}$ & $\mathbf{C}$ & $\mathbf{C}$ \\
$\begin{array}{l}\text { Talk with the victim } \\
\text { Take away bully's } \\
\text { privleges }\end{array}$ & $\mathbf{C}$ & $\mathbf{C}$ & $\mathbf{C}$ & $\mathbf{C}$ & $\mathbf{C}$ \\
$\begin{array}{l}\text { Mediate / Problem solve } \\
\text { with bully and victim }\end{array}$ & $\mathbf{C}$ & $\mathbf{C}$ & $\mathbf{C}$ & $\mathbf{C}$ & $\mathbf{C}$ \\
& Very & Unlikely & Undecided & Likely & Very Likely \\
$\begin{array}{l}\text { Report incident to bully's } \\
\text { parents }\end{array}$ & $\mathbf{C}$ & $\mathbf{C}$ & $\mathbf{C}$ & $\mathbf{C}$ & $\mathbf{C}$ \\
$\begin{array}{l}\text { Report incident to } \\
\text { victim's parents }\end{array}$ & $\mathbf{C}$ & $\mathbf{C}$ & $\mathbf{C}$ & $\mathbf{C}$ & $\mathbf{C}$ \\
$\begin{array}{l}\text { Report incident to school } \\
\text { administrators }\end{array}$ & $\mathbf{C}$ & $\mathbf{C}$ & $\mathbf{C}$ & $\mathbf{C}$ & $\mathbf{C}$ \\
Other (specify) & $\mathbf{C}$ & $\mathbf{C}$ & $\mathbf{C}$ & $\mathbf{C}$ & $\mathbf{C}$ \\
\hline
\end{tabular}

When aware of students' bullying away from school, how likely are you to take the following actions?

$\begin{array}{llllll} & \text { Very } & \text { Unlikely } & \text { Undecided } & \text { Likely } & \text { Very Likely } \\ \text { Do nothing } & \text { Unlikely } & \text { C } & \text { C } & \text { C } & \text { C } \\ \text { Talk with the bully } & \mathbf{C} & \mathbf{C} & \mathbf{C} & \mathbf{C} & \mathbf{C} \\ \text { Talk with the victim } & \mathbf{C} & \mathbf{C} & \mathbf{C} & \mathbf{C} & \mathbf{C} \\ \begin{array}{l}\text { Take away bully's } \\ \text { privleges }\end{array} & \mathbf{C} & \mathbf{C} & \mathbf{C} & \mathbf{C} & \mathbf{C} \\ \begin{array}{l}\text { Mediate / Problem solve } \\ \text { with bully and victim }\end{array} & \mathbf{C} & \mathbf{C} & \mathbf{C} & \mathbf{C} & \mathbf{C} \\ & \text { Very } & \text { Unlikely } & \text { Undecided } & \text { Likely } & \text { Very Likely }\end{array}$


When aware of students' bullying away from school, how likely are you to take the following actions?

\begin{tabular}{llllll} 
& $\begin{array}{l}\text { Very } \\
\text { Unlikely }\end{array}$ & Unlikely & Undecided & Likely & Very Likely \\
$\begin{array}{l}\text { Report incident to bully's } \\
\text { parents }\end{array}$ & $\mathbf{C}$ & $\mathbf{C}$ & $\mathbf{C}$ & $\mathbf{C}$ & $\mathbf{C}$ \\
$\begin{array}{l}\text { Report incident to } \\
\text { victim's parents }\end{array}$ & $\mathbf{C}$ & $\mathbf{C}$ & $\mathbf{C}$ & $\mathbf{C}$ & $\mathbf{C}$ \\
$\begin{array}{l}\text { Report incident to school } \\
\text { administrators } \\
\text { Other (specify) }\end{array}$ & $\mathbf{C}$ & $\mathbf{C}$ & $\mathbf{C}$ & $\mathbf{C}$ & $\mathbf{C}$ \\
\hline
\end{tabular}

When aware of students' cyber bullying at your school, how likely are you to take the following actions?

\begin{tabular}{|c|c|c|c|c|c|}
\hline & $\begin{array}{l}\text { Very } \\
\text { Unlikely }\end{array}$ & Unlikely & Undecided & Likely & Very Likely \\
\hline Do nothing & $\mathbb{E}$ & $\mathbb{C}$ & $\mathbb{G}$ & $\mathbb{C}$ & $\mathbb{G}$ \\
\hline Talk with the cyber bully & E & $\mathbb{C}$ & $\mathrm{C}$ & C & $\mathbb{C}$ \\
\hline Talk with the victim & C & $\mathbb{C}$ & $\mathbb{G}$ & $\mathbb{C}$ & $\mathbb{E}$ \\
\hline $\begin{array}{l}\text { Take away cyber bully's } \\
\text { privleges }\end{array}$ & C & $\mathrm{C}$ & $\mathbb{E}$ & $\mathrm{C}$ & $\mathrm{C}$ \\
\hline \multirow[t]{2}{*}{$\begin{array}{l}\text { Mediate / Problem solve } \\
\text { with cyber bully and } \\
\text { victim }\end{array}$} & E & $\mathbb{C}$ & $\mathbb{G}$ & $\mathbb{C}$ & $\mathbb{G}$ \\
\hline & $\begin{array}{l}\text { Very } \\
\text { Unlikely }\end{array}$ & Unlikely & Undecided & Likely & Very Likely \\
\hline $\begin{array}{l}\text { Report incident to cyber } \\
\text { bully's parents }\end{array}$ & $\mathrm{C}$ & $\mathbb{C}$ & $\mathbb{C}$ & $\mathrm{C}$ & $\mathrm{C}$ \\
\hline $\begin{array}{l}\text { Report incident to } \\
\text { victim's parents }\end{array}$ & C & $\mathbb{C}$ & $\mathbb{C}$ & $\mathrm{C}$ & $\mathrm{C}$ \\
\hline $\begin{array}{l}\text { Report incident to school } \\
\text { administrators }\end{array}$ & C & $\mathbb{C}$ & $\mathbb{C}$ & C & $\mathbb{C}$ \\
\hline Other (specify) & 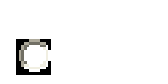 & $\mathbb{C}$ & $\mathbb{E}$ & $\mathbb{C}$ & $\mathbb{C}$ \\
\hline
\end{tabular}

When aware of students' cyber bullying away from school, how likely are you to take the following actions?

\begin{tabular}{|c|c|c|c|}
\hline $\begin{array}{l}\text { Very } \\
\text { Unlikely }\end{array}$ & Unlikely & Undecided & Likely \\
\hline $\mathrm{C}$ & $\mathrm{C}$ & $C$ & $C$ \\
\hline$C$ & $\mathrm{C}$ & 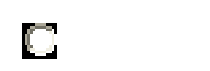 & $C$ \\
\hline$C$ & $\mathrm{C}$ & 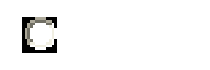 & $C$ \\
\hline $\mathrm{C}$ & $\mathrm{C}$ & $\mathbb{C}$ & $C$ \\
\hline
\end{tabular}


When aware of students' cyber bullying away from school, how likely are you to take the following actions?

\begin{tabular}{|c|c|c|c|c|c|}
\hline \multirow{3}{*}{$\begin{array}{l}\text { privleges } \\
\text { Mediate / Problem solve } \\
\text { with cyber bully and } \\
\text { victim }\end{array}$} & $\begin{array}{l}\text { Very } \\
\text { Unlikely }\end{array}$ & Unlikely & Undecided & Likely & Very Likely \\
\hline & $C$ & $\mathrm{C}$ & $\mathrm{C}$ & $C$ & $C$ \\
\hline & $\begin{array}{l}\text { Very } \\
\text { Unlikely }\end{array}$ & Unlikely & Undecided & Likely & Very Likely \\
\hline $\begin{array}{l}\text { Report incident to cyber } \\
\text { bully's parents }\end{array}$ & $\mathrm{C}$ & $\mathrm{C}$ & $\mathrm{C}$ & $C$ & $C$ \\
\hline $\begin{array}{l}\text { Report incident to } \\
\text { victim's parents }\end{array}$ & $\mathbf{C}$ & $\mathrm{C}$ & $\mathrm{C}$ & $\mathbb{C}$ & $C$ \\
\hline $\begin{array}{l}\text { Report incident to school } \\
\text { administrators }\end{array}$ & $\mathrm{C}$ & $\mathrm{C}$ & $\mathrm{C}$ & $\mathrm{C}$ & $\mathbb{C}$ \\
\hline Other (specify) & 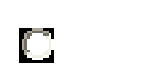 & $\mathbb{C}$ & 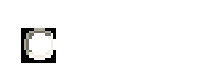 & $\mathrm{C}$ & $\mathrm{C}$ \\
\hline
\end{tabular}

What barriers make it difficult to address bullying?

What barriers make it difficult to address cyber bullying?

Share your ideas about what works to decrease bullying.

Share your ideas about what works to decrease cyber bullying.

Any other comments, concerns or clarifications?
Gender
C Male
C Female 
Years working as a teacher (include internship and part-time years)

Years in [the] School District

Highest Level of Education

C Less than High School

C High School/ GED

C Associates

C Bachelors

C. Masters

C Specialist

C Doctorate

C Other (specify)

Grade levels you currently teach or supervise (check all that apply)

\begin{tabular}{|c|c|c|c|c|c|}
\hline Г Pre-School & $\Gamma$ & $3 \mathrm{rd}$ & $\Gamma$ & 7 th & $\Gamma$ \\
\hline$\ulcorner$ Kindergarten & $\Gamma$ & 4 th & $\Gamma$ & 8th & $\Gamma$ \\
\hline Г $1 \mathrm{st}$ & $\Gamma$ & 5 th & Г & 9 th & $\Gamma$ \\
\hline - 2 nd & $\Gamma$ & 6 th & & & \\
\hline
\end{tabular}

Groups of students you currently teach or supervise (check all that apply)

$\ulcorner$ General Education $\quad \Gamma$ Special Education $\quad\ulcorner$ Youth in Custody 


\section{THESIS REFERENCES}

Agatston, P. W., Kowalski, R., \& Limber, S. (2007). Students' perspectives on cyber bullying. Journal of Adolescent Health, 41, 59-60.

The Alannah and Madeline Foundation, in consultation with the National Coalition Against Bullying and Center for Strategic Education. (2007). Cyber-safety Symposium Report. Melbourne, Australia: Author.

Beale, A. V., \& Hall, K. R. (2007). Cyberbullying: What school administrators (and parents) can do. Clearing House: A Journal of Educational Strategies, Issues and Ideas, 81(1), 8-12.

Berger, K. S. (2007). Update on bullying at school: Science forgotten? Developmental Review, 27(1), 90-126.

Bhat, C. S. (2008). Cyber bullying: Overview and strategies for school counselors, guidance officers, and all school personnel. Australian Journal of Guidance and Counseling, 18(1), 53-66.

Biggs, B. K., Vernberg, E. M., Twemlow, S. W., Fonagy, P., \& Dill, E. J. (2008). Teacher adherence and its relation to teacher attitudes and student outcomes in an elementary school-based violence prevention program. School Psychology Review, 37(4), 533-549.

Bird, S. (2009). Holly Grogan, 15, leapt to her death 'after abuse from Facebook bullies.' The Times. Retrieved from http://www.timesonline.co.uk/tol/news/uk/article6841908.ece

Bradshaw, C. P., Sawyer, A. L., \& O’Brennan, L. M. (2007). Bullying and peer victimization at school: Perceptual differences between students and school staff. School Psychology Review, 36(3), 361-382.

Cohen, J. (1988). Statistical power analysis for the behavioral sciences (2nd ed.). Hillsdale, NJ: Erlbaum. 
Cohen, J. (1994). The earth is round (p .05). American Psychologist, 49, 997-1003.

Dake, J. A., Price, J. H., Telljohann, S. K., \& Funk, J. B. (2003). Teacher perceptions and practices regarding school bullying prevention. Journal of School Heath, 73(9), 347-355.

DeBell, M., \& Chapman, C. (2006). Computer and Internet use by students in 2003 (NCES 2006-065). Washington, DC: U.S. Department of Education. Retrieved from http://nces.ed.gov/pubs2006/2006065.pdf

Ferguson, C. J., Miguel, C. S., Kilburn, J. C., \& Sanchez, P. (2007). The effectiveness of schoolbased anti-bullying programs: A meta-analytic review. Criminal Justice Review, 32(4), $401-414$.

Finkelhor, D., Ormrod, R., Turner, H., \& Hamby, S. L. (2005). The victimization of children and youth: A comprehensive, national survey. Child Maltreatment, 10, 5-25.

Forman, S. G., Olin, S. S., Hoagwood, K. E., Crowe, M., \& Saka, N. (2009). Evidence-based interventions in schools: Developers' views of implementation barriers and facilitators. School Mental Health, 1(1), 26-36.

Greene, M. (2000). Bullying and harassment in schools. In R. Moser \& C. Frantz (Eds.), Shocking violence: Youth perpetrators and victims--A multidisciplinary perspective (pp. 72-101). Springfield, IL: Charles C. Thomas.

Gurian, A. (n.d.). Kids and cell phones: Staying connected. Retrieved from http://www.aboutourkids.org/articles/kids_cell_phones_staying_connected

Hawker, D., \& Boulton, M. (2000). Twenty years' research on peer victimization and psychosocial maladjustment: A meta-analytic review of cross-sectional studies. Journal of Child Psychology and Psychiatry, 41(4), 441-455. 
Hirschstein, M. K., Edstrom, L.V.S., Frey, K. S., Snell, J. L., \& MacKenzie, E. P. (2007). Walking the talk in bullying prevention: Teacher implementation variables related to initial impact of the Steps to Respect program. School Psychology Review, 36(1), 3-21.

Hinduja, S., \& Patchin, J. W. (2007). Offline consequences of online victimization: School violence and delinquency. Journal of School Violence, 6(3), 89-112.

Hinduja, S., \& Patchin, J. W. (2010). Bullying, cyberbullying, and suicide. Archives of Suicide Research, 14, 206-221.

Kennedy, K. (2006). Not-so-MySpace anymore. The Ledger.com. Retrieved from http://www.theledger.com/apps/pbcs.dll/article?AID=/20060423/NEWS/604230392/1/NEWS0101

Kowalski, R. M., \& Limber, S. P. (2007). Electronic bullying among middle school students. Journal of Adolescent Health, 41, 22-30.

Kowalski, R. M., Limber, S. P., \& Agatston, P. W. (2008). Cyber Bullying: Bullying in the digital age. Malden, MA: Blackwell Publishing.

LaRusso, M. D., Romer, D., \& Selman, R. L. (2007). Teachers as builders of respectful school climates: Implications for adolescent drug use norms and depressive symptoms in high school. Journal of Youth and Adolescence, 37(4), 386-398.

Lenhart, A., Madden, M., \& Hitlin, P. (2005). Teens and technology. Retrieved from http://www.pewinternet.org/Reports/2005/Teens-and-Technology.aspx

Lenhart, A. (2009). Teens and mobile phones over the past five years: Pew internet looks back. Retrieved from http://www.pewinternet.org/Reports/2009/14--Teens-and-Mobile-PhonesData-Memo.aspx 
Limber, S. P. (2004). Implementation of the Olweus Bullying Prevention Program in American schools: Lessons learned from the field. In D. L. Espelage \& S. M. Swearer (Eds.), Bullying in American schools: A social-ecological perspective on prevention and intervention (pp. 351-363). Mahwah, NJ: Lawrence Erlbaum.

Li, Q. (2006). Cyber bullying in schools: A research of gender differences. School Psychology International, 27(2), 157-170.

Li, Q. (2007). New bottle but old wine: A research of cyberbullying in schools. Computers in Human Behavior, 23, 1777-1791.

Li, Q. (2008). Cyberbullying in schools: An examination of preservice teachers' perception. Canadian Journal of Learning and Technology, 34(2), 75-90.

Merrell, K. W., Gueldner, B. A., Ross, S. W., \& Isava, D. M. (2008). How effective are school bullying intervention programs? A meta-analysis of intervention research. School Psychology Quarterly, 23(1), 26-42.

Nansel, T. R., Overpeck, M. D., Pilla, R. S., Ruan, W. J., Simmons-Morton, B., \& Scheidt, P. (2001). Bullying behavior among U.S. youth: Prevalence and association with psychosocial adjustment. Journal of the American Medical Association, 285, 2094-2100.

Olweus, D. (1993). Bullying at school: What we know and what we can do. Cambridge, MA: Blackwell.

Olweus, D. (2003). A profile of bullying at school. Educational Leadership, 60(6), 12-17.

Payne, A., Gottfredson, D. C., \& Gottfredson, G. D. (2006). School predictors of the intensity of implementation of school-based prevention programs: Results from a national study. Prevention Science, 7, 225-237. 
Raskauskas, J., \& Stoltz, A.D. (2007). Involvement in traditional and electronic bullying among adolescents. Developmental Psychology, 43(3), 564-575.

Rigby, K. (2003). Consequences of bullying in schools. The Canadian Journal of Psychiatry/La Revue Canadienne de Psychiatrie, 48(9), 583-590.

Sassu, K. A. (2006). Teachers' perceptions of bullying: An investigation of reported characteristic behaviors and the likelihood of intervention in response to overtly and relationally aggressive behavior. Retrieved from PsycINFO database.

Slavin, R. E. (2006). Translating research into widespread practice: The case of success for all. In M. A. Constas \& R. J. Sternberg (Eds.), Translating theory and research into educational practice: Developments in content domains, large scale reform, and intellectual capacity (pp. 113-127). Mahwah, NJ: Lawrence Erlbaum.

Slonje, R., \& Smith, P. K. (2008). Cyberbullying: Another main type of bullying? Scandinavian Journal of Psychology, 49, 147-154.

Smith, J. D., Schneider, B. H., Smith, P. K., \& Ananiadou, K. (2004). The effectiveness of whole-school anti-bullying programs: A synthesis of evaluation research. School Psychology Review, 33 (4), 547-560.

Smith, P. K., \& Brain, P. (2000). Bullying in schools: Lessons from two decades of research. Aggressive Behavior, 26, 1-9.

Smith, P. K., Mahdavi, J., Carvalho, M., Fisher, S., Russell, S., \& Tippett, N. (2008). Cyberbullying: Its nature and impact in secondary schools. Journal of Child Psychology and Psychiatry, 49(4), 376-385.

Thompson, B. (2007). Effect sizes, confidence intervals, and confidence intervals for effect sizes. Psychology in the Schools, 44(5), 423-432. 
Tinker v. Des Moines Independent Community School District. (1969). 393 U.S. 503.

United States Department of Education, National Center for Education Statistics. (2007, July). Public schools and instructional rooms with internet access, by selected school characteristics: Selected years, 1994 through 2005 (Table 413, Digest of Education Statistics, Fast Response Survey System). Retrieved from http://nces.ed.gov/programs/digest/d07/tables/dt07_413.asp

United States Department of Education, National Center for Education Statistics. (2009a). Common core of data: Public school student membership, by race/ethnicity and state or jurisdiction: School year 2006-07. Retrieved from http://nces.ed.gov/CCD/tables/2009305_02.asp

United States Department of Education, National Center for Education Statistics. (2009b). Participation in education: Racial/ethnic enrollment in public schools. Retrieved from http://nces.ed.gov/programs/coe/2009/section1/indicator07.asp

United States Department of Education, National Center for Education Statistics. (2009c). Participation in education: Table A-8-3. Number and percentage of children ages 5-17 who spoke a language other than English at home and who spoke English with difficulty, by language spoken, region, and state: 2007. Retrieved from http://nces.ed.gov/programs/coe/2009/section1/table-lsm-3.asp

United States Department of Education, National Center for Education Statistics. (2010). Special analysis 2010: High poverty public schools. Retrieved from http://nces.ed.gov/programs/coe/2010/analysis/index.asp 
Vandebosch, H., \& Van Cleemput, K. (2007). Cyber bullying among youngsters. Conference Papers -- International Communication Association. Retrieved from Communication \& Mass Media Complete database.

Willard, N. E. (2007a). The authority and responsibility of school officials in responding to cyberbullying. Journal of Adolescent Health, 41, 64-65.

Willard, N. E. (2007b). Educator's guide to cyberbullying: Addressing the harm caused by online social cruelty. Retrieved from http://www.asdk12.org/MiddleLink/AVB/bully_topics/EducatorsGuide_Cyberbullying.p $\mathrm{df}$

Wilkinson, L., \& Task Force on Statistical Inference, American Psychological Association, Science Directorate. (1999). Statistical methods in psychology journals: Guidelines and explanations. American Psychologist, 54, 594-604.

Ybarra, M. L., \& Mitchell, K. J. (2004a). Online aggressor/targets, aggressors, and targets: A comparison of associated characteristics. Journal of Child Psychology and Psychiatry, 45(7), 1308-1316.

Ybarra, M. L., \& Mitchell, K. J. (2004b). Youth engaging in online harassment: Associations with caregiver-child relationships, Internet use, and personal characteristics. Journal of Adolescence, 27, 319-336.

Zande, K. (2009). When the school bully attacks in the living room: Using tinker to regulate Off-campus student cyberbullying. Barry Law Review 13(103). Retrieved from LexisNexis Academic database. 